\title{
Corporate Governance and Conditional Skewness in the World's Stock Markets*
}

\author{
Kee-Hong Bae \\ Queen's University \\ Chanwoo Lim \\ Korea University \\ K.C. John Wei \\ Hong Kong University of Science and Technology
}

\begin{abstract}
* We are grateful for comments from Warren Bailey, Stijn Claessens, Joseph Fan, Jie Gan, Gilles Hilary, Bong-Chan Kho, Sheridan Titman, and seminar participants at Hong Kong University of Science and Technology, Korea University, National University of Singapore, University of New South Wales, the Western Finance Association 2003 Meetings, and the 2005 China International Conference in Finance. We thank an anonymous referee for insightful comments that guided us to improve the paper significantly. We also thank Dr. Virginia Unkefer for editorial assistance. Bae acknowledges research support from the Asian Institute of Corporate Governance at Korea University. Bae and Wei acknowledge financial support from an RGC Competitive Earmarked Research Grant of the Hong Kong Special Administration Region, China (project no.: HKUST6237/03H). All errors are our own. Contact the corresponding author, K.C. John Wei, at johnwe@ust.hk.
\end{abstract}




\begin{abstract}
We investigate why stock returns in emerging markets tend to be more positively skewed than those in developed markets tend to be. We argue that differences in the quality of corporate governance matter to return skewness. Using return data from more than 14,000 individual stocks in 38 countries, we find that positive skewness is most profound in stocks from markets that have poor corporate governance. Our results are robust to a variety of model specifications, different measures of return asymmetries, and alternative measures of corporate governance. Finally, analogous results are also obtained from aggregate stock market returns.
\end{abstract}




\section{Introduction}

It is now well known that stock returns in emerging markets are characterized by higher average returns and higher volatilities than are those in developed markets. Less known is the fact that stock returns in emerging markets are more positively skewed than are those in developed markets. In this paper, we investigate why stock returns in emerging markets tend to be more positively skewed than stock returns in developed markets tend to be. ${ }^{1}$

We argue that differences in the quality of corporate governance matter to stock return skewness. There are at least two reasons why the quality of corporate governance is related to return asymmetries. First, as Morck, Yeung, and Yu (2000) argue, countries that protect public investors’ property rights do not facilitate intercorporate income shifting by controlling insiders among affiliated firms of business groups or business segments. In contrast, in countries with poor property rights, it is more advantageous for firms in business groups to use internal markets rather than external markets to smooth and diversify their income flows. ${ }^{2}$

Risk sharing appears to be an important motivation for business groups that are ubiquitous in most emerging markets. Friedman, Johnson, and Mitton (2003) argue that entrepreneurs in emerging markets often use resources from other businesses that they control to bail out troubled companies. Chang and Hong (2000) show that business groups in Korea use extensive crosssubsidization such as debt guarantees, equity investments, and internal transactions to support poorly performing firms at the expense of well-performing firms. Mitton (2002) finds evidence of "propping” in diversified firms in Indonesia, the Philippines, Korea, Malaysia, and Thailand during the Asian financial crisis of 1997-98. By studying the takeover market in Korea, Bae, Kang, and Kim (2002) show that financially distressed targets that belong to business groups are

\footnotetext{
1 In Section III, we discuss in detail the evidence that stock returns in emerging markets are more positively skewed than are those in developed markets.

${ }^{2}$ Please see Khanna and Yafeh (2005) and the references therein.
} 
likely to be merged with more successful member firms, even when such transactions do not maximize the value of the bidding firms.

Bailing out a distressed firm can lead to a credible commitment by a business group to prop up the performance of its member firms. This will allow the stock returns of firms belonging to the business group to be more positively skewed since a negative shock would not be fully reflected in the stock returns of the member firms due to the implicit guarantee of a bailout. Put differently, investors may perceive a put option to be a potential bailout of firms belonging to a business group. In contrast, an equally negative shock would be fully reflected in the stock returns of independent firms that do not have bailout guarantees. This risk-sharing hypothesis suggests that, due to cross-subsidies among group-affiliated firms, earnings or returns of groupaffiliated firms are more positively skewed than they are for independent firms. Since business groups are a more prevalent organizational form in emerging markets, positive skewness is more pronounced in emerging markets.

Second, stock markets in countries characterized by poor corporate governance tend to have poor information disclosure. ${ }^{3}$ In the U.S., corporate managers are subject to many governance mechanisms that force them to act in the best interests of shareholders. These corporate governance mechanisms are nonexistent or are not practiced in many emerging markets. The lack of mechanisms to govern managerial discretion would allow firm managers in these markets to have more discretionary power over the disclosure of information. Managers in emerging market firms would have a greater discretion to hide bad news or to release bad news slowly. This managerial behavior imparts a degree of positive skewness in stock returns in emerging markets.

\footnotetext{
${ }^{3}$ An analysis of recent surveys by Credit Lyonnais Securities Asia (2001, 2002) and Standard and Poor’s (2002) confirms that disclosure and corporate governance are significantly positively correlated.
} 
These two factors — risk sharing and discretionary disclosure by managers — lead to positive skewness in stock markets with poor corporate governance. As a result, stock returns in economies characterized by poor corporate governance are likely to be more positively skewed. Furthermore, stock returns of firms with poor governance within a country are also likely to be more positively skewed. ${ }^{4}$

We find several empirical results that are consistent with our hypothesis. Using firm-level return data from more than 14,000 stocks in 38 countries from 1995 to 2003 and the earnings management scores reported by Leuz, Nanda, and Wysocki (2003) as a measure of corporate governance (with a higher score indicating poorer corporate governance), we show that positive return skewness is more pronounced in stocks from markets that have poorer corporate governance. This evidence is consistent with the risk-sharing hypothesis and/or the discretionarydisclosure hypothesis and underscores the importance of corporate governance in explaining cross-sectional differences in return asymmetries across countries.

The significance of the corporate governance variable in explaining stock return skewness is robust to a variety of regression specifications. The results are robust regardless of whether returns are measured in local currencies or in U.S. dollars, whether or not GDP per capita is included in the multivariate regressions, or how return asymmetries are measured. The results are also robust to the use of various indexes of corporate governance from different sources. Analogous results are also obtained when aggregate market returns are used to explain skewness across countries.

Our main argument about return asymmetries is based on the observation of the asymmetric release of information in poor corporate governance firms, with much information released with

\footnotetext{
${ }^{4}$ While we argue that both risk sharing and discretionary disclosure are the two factors explaining cross-sectional differences in return asymmetries across countries, our empirical test focuses mainly on the discretionary-disclosure hypothesis due to the lack of business group data for many of our sample countries.
} 
good news, but limited information released with bad news. However, bad news will be revealed eventually. If this is the case, one would expect that extremely negative rates of return would occur more often in firms or countries with poor corporate governance than in those with good corporate governance. Consistent with this prediction, we find that extremely negative rates of return occur significantly more often in countries with poor corporate governance than in countries with good corporate governance.

There is now a large literature that highlights the importance of corporate governance in the various aspects of financial markets. ${ }^{5}$ La Porta et al. $(1997,1998,2000,2002)$ argue that the legal protection of investors is a particularly important manifestation of effective corporate governance. We contribute to this growing literature by showing that the quality of corporate governance also affects the distributional characteristics of stock returns and by explaining why stock returns in emerging markets tend to be more positively skewed than those in developed markets tend to be.

The remainder of the paper is organized as follows. In Section II, we review the related literature and develop our main hypothesis. In Section III, we describe the data and present the evidence that stock returns are more positively skewed in emerging markets than they are in developed markets. In Section IV, we report our main empirical results from firm-level return data. We also report on a number of robustness checks. In Section V, we use return data from aggregate stock markets for additional robustness checks. Finally, we conclude our paper in Section VI.

\footnotetext{
${ }^{5}$ Please see Section II.B for detailed discussions.
} 


\section{Related Literature and Hypothesis Development}

To motivate our empirical specifications, we review the literature on return asymmetries and suggest a rationale for the linkage between corporate governance and return asymmetries.

\section{A. Related Literature on Asymmetries in Stock Returns}

Stock return distribution assumptions have been very important in deriving portfolio theory, capital asset-pricing models, and option pricing models. The assumption of a mean-variance return distribution, including normal and lognormal distributions, is most commonly adopted in these models. However, it is well documented that stock returns are asymmetrically distributed. Specifically, negative skewness in daily returns has been found in several aggregate stock market indexes, including U.S. market indexes. Previous studies have focused on how skewness affects asset-pricing models, ${ }^{6}$ while recent research has examined how skewness affects option pricing. ${ }^{7}$

A number of theories have attempted to offer possible explanations for negative asymmetries in aggregate stock market returns and the cross-sectional variation of conditional skewness in individual stocks. ${ }^{8}$ The earliest theory to explain negative asymmetries in stock market returns is based on leverage effects as proposed by Black (1976) and Christie (1982). The leverage-effects hypothesis suggests that when a stock price drops, the financial and operating leverage of the firm increases, which increases the subsequent stock return volatility. On the other hand, when a stock price rises, the financial and operating leverage of the firm declines, decreasing subsequent stock return volatility. This asymmetric volatility reaction to the rise and fall of stock prices

\footnotetext{
${ }^{6}$ To understand how skewness affects asset-pricing models, please see Kraus and Litzenberger (1976), Friend and Westerfield (1980), Sears and Wei (1985), and Harvey and Siddique (2000), among others.

${ }^{7}$ To understand how skewness affects option pricing, please refer to Das and Sundaram (1999) and Chen et al. (2001)

${ }^{8}$ Notice that the previous literature on return asymmetries attempts to explain negative skewness in aggregate stock market returns in developed markets, whereas our study attempts to explain why stock returns at the firm level and at the aggregate market level are more positively skewed in emerging markets than they are in developed markets.
} 
causes stock returns to be negatively skewed. However, Schwert (1989) and Bekaert and Wu (2000) document that leverage effects are not sufficient enough to explain the magnitude of the observed negative asymmetries in aggregate stock market returns.

A second explanation for the negative skewness in stock market returns is based on the stochastic-bubble model developed by Blanchard and Watson (1982). The stochastic-bubble hypothesis suggests that negative asymmetries in stock market returns are generated from popping the bubble, which produces very large negative returns, although the probability for this is very low.

A third theory to explain negative asymmetries in stock market returns comes from the volatility-feedback hypothesis suggested by Pindyck (1984), French, Schwert, and Stambaugh (1987), Campbell and Hentschel (1992), and others. The theory of volatility feedback argues that the arrival of either good news or bad news signals an increase in market volatility, which in turn increases the risk premium. This increase in the risk premium offsets part of the positive effect of the good news (cashflow increase), but it amplifies the negative effect of the bad news (cashflow decrease). As a result, stock prices drop more when there is bad news in the market than when there is good news, which leads to negatively skewed stock returns. Although the theory of volatility feedback is attractive, Poterba and Summers (1986) counter-argue that most market volatility shocks are very short-lived and, hence, changes in market volatility cannot be expected to have an important impact on the risk premium. As a result, the volatility-feedback hypothesis cannot account for large proportions of the negative asymmetries in stock market returns.

A recent model, called the difference-of-opinion model, developed by Hong and Stein (2003), suggests that investor heterogeneity is the major reason for negative return asymmetries. Using data from the U.S., Chen, Hong, and Stein (2001) have comprehensively examined the 
cross-sectional determination of conditional skewness in the daily returns of individual stocks and in the time series of aggregate market daily returns. They find that negative skewness is most profound in stocks that have experienced an increase in trading volume relative to the trend over the previous six months and have had higher returns over the previous 36-month period. The first finding appears to support the differences-of-opinion model and the second finding appears to support the stochastic-bubble theory.

The last and most notable hypothesis, for our purposes at least, is the discretionary-disclosure hypothesis. This hypothesis argues that managers have some degree of discretion over the disclosure of information and that they prefer to announce good news immediately but allow bad news to dribble out slowly. This managerial behavior will then impart a degree of positive skewness in stock returns. Furthermore, this managerial discretion tends to be more pronounced in small-capitalization firms or in firms followed by fewer analysts, since managers of these firms have a wider scope for hiding bad news from the market. In fact, Harvey and Siddique (2000) and Chen et al. (2001) find that skewness is more positive on average for smallcapitalization firms. Moreover, Chen et al. (2001) and Damodaran (1987) find that skewness is more positive for firms followed by fewer analysts.

\section{B. $\quad$ Corporate Governance and Return Asymmetries in Stock Returns}

There are now numerous studies that show the impact of investor protection (or the quality of corporate governance in general) on the various aspects of financial markets. For example, La Porta et al. $(1997,1998)$ show that stock markets in better corporate governance countries have larger and deeper capital markets, while La Porta et al. (2002) and Claessens et al. (2002) find that stock markets in stronger corporate governance countries or firms have higher firm 
valuations. In addition, stronger investor protection is also shown to be associated with a higher number of listed firms (La Porta et al., 1997) and greater use of external financing (La Porta et al., 1998). Demirgüç-Kunt and Maksimovic (1998) find that, in countries with higher scores on a legal efficiency index, a greater proportion of firms use long-term external financing.

Johnson et al. (2003) and Mitton (2002) report that strong corporate governance countries can endure market declines better than poor corporate governance countries can during a financial crisis. Hung (2001), Ball, Robin, and Wu (2003), Fan and Wong (2002), and Leuz et al. (2003) document that good corporate governance countries provide higher quality of accounting information than do poor corporate governance countries. Morck et al. (2000) show that stock prices move together more in poor countries than they do in rich countries and attribute this stock return synchronicity to the poor property rights protection of public investors, which impedes informed arbitrageurs to capitalize on firm-specific information. That is, stock markets in good corporate governance countries are more useful as processors of economic information than are stock markets in poor corporate governance countries. However, to the best of our knowledge, no previous study has analyzed the distributional characteristics of stock returns in poor corporate governance countries. ${ }^{9}$

In the following sections, we document evidence that shows that stock returns in emerging markets are more positively skewed than are those in developed markets. We then test the predictions of the discretionary-disclosure hypothesis using firm-level data from 38 countries around the world.

\footnotetext{
${ }_{9}$ Although Bris, Goetzmann, and $\mathrm{zhu}$ (2003) examine the impact of a good corporate governance index on return skewness, their focus is on whether short-sale restrictions affect the stock returns, not specifically on whether the quality of governance matters to return skewness.
} 


\section{Data and the Construction of Variables}

A. Data

We first started with the list of 50 countries covered by Datastream International for which common stock return data are available. Out of these 50 countries, data on the anti-director rights index as constructed by La Porta et al. (1998) are available for 40 countries. We dropped Egypt and Sri Lanka since these countries have too few firms, leaving us a final sample of 38 countries. For each firm in each of these 38 countries, we collected daily stock returns, trading volume, and market capitalization information during the period from 1995 to $2003 .{ }^{10}$ To obtain more reliable estimates for return asymmetries in any calendar year, we required that a firm-year should have at least 200 days of daily returns during any particular year. This sample selection process resulted in a final sample of 14,136 individual firms from 38 countries.

Table 1 presents some distributional characteristics of the daily local-currency, firm-level stock returns of our sample countries. In each year and for each firm in each country, we computed sample statistics (mean, standard deviation, the first quartile, and the third quartile) and reported here the average of a sample statistic for each country. We also partitioned the sample countries into two groups, emerging markets and developed markets, by a cutoff point of average GDP per capita of US\$15,000. The average (median) GDP per capita in emerging markets is US\$5,370 (US\$3,777), while it is US\$25,693 (US\$24,231) in developed markets, five (six) times as large as the figure in emerging markets. The average daily returns, expressed in basis points, are higher in emerging markets. Not surprisingly, the average standard deviations are also higher in emerging markets. The average daily standard deviation in emerging markets

\footnotetext{
${ }^{10}$ This is a period that is characterized by financial markets around the world being very volatile. During this period, the Asian financial crisis started in July 1997, the Russian debt crisis occurred in July 1998, the Internet bubble grew prior to the change of the millennium and it burst in mid-2000.
} 
is 3.28 percent, which translates into an annual volatility of 52.28 percent. The corresponding annual volatility in developed markets is 46.06 percent. ${ }^{11}$ The sixth and seventh columns of Table 1 show the first quartile and third quartile returns, respectively. The average ranges of these quartiles are larger in emerging markets than in developed markets, confirming that there are higher volatilities in emerging markets.

\section{B. Measures of Return Asymmetries}

The first measure of return asymmetry is the conditional coefficient of skewness, which we call SKEW. SKEW is computed by taking the sample's third moment of daily returns and dividing it by the sample variance of daily returns raised to the power of $3 / 2$. Specifically, SKEW for stock index $i$ over the sample period is calculated as follows: ${ }^{12}$

$$
S K E W_{i}=\frac{(n(n-1))^{3 / 2} \sum_{\tau=1}^{n} R_{i \tau}^{3}}{(n-1)(n-2)\left(\sum_{\tau=1}^{n} R_{i \tau}^{2}\right)^{3 / 2}}
$$

where $R_{i \tau}$ represents the daily demeaned return for stock $i$ on day $\tau$ and $n$ is the number of observations of daily returns during the sample period. Daily returns are computed as $\ln \left[\left(P_{i \tau}+\right.\right.$ $\left.\left.D_{i \tau}\right) / P_{i \tau-1}\right]$, where $P_{i \tau}$ is the stock price at the close of day $\tau$ and $D_{i \tau}$ is the dividend. Scaling the raw third moment by the cubed standard deviation allows us to compare stocks with different volatilities. A larger positive (negative) value in SKEW is associated with a stock that has a more right-skewed (left-skewed) return distribution.

In addition to $S K E W$, we compute an alternative measure of positive skewness that does not involve the third moment and hence is less likely to be particularly influenced by a small number

\footnotetext{
${ }^{11}$ The reason for high volatility in our sample is due to the fact that the financial markets were very volatile during our sample period.

${ }^{12}$ Basically, we follow the measure of skewness used by Chen et al. (2001).
} 
of extreme returns. This alternative measure of skewness is denoted as VOLRATIO, for the "upto-down volatility ratio.” VOLRATIO for stock $i$ over the sample period is calculated as follows:

$$
\text { VOLRATIO }_{i}=\ln \left\{\frac{\left(n_{d}-1\right) \sum_{\tau \in U P} R_{i \tau}^{2}}{\left(n_{u}-1\right) \sum_{\tau \in \text { DOWN }} R_{i \tau}^{2}}\right\},
$$

where $n_{u}$ and $n_{d}$ are the number of up and down days, respectively. An up (a down) day is a day on which the stock return is above (below) the sample mean during the sample period. That is, we separate the daily return observations during the sample period into two sub-samples: those returns above the sample mean and those returns below the sample mean. We then calculate the sample variance separately for each sub-sample and take the logarithm of the ratio of the sample variance from the up days to the sample variance from the down days. A larger positive (negative) value in VOLRATIO is associated with a stock that has a more right-skewed (leftskewed) return distribution.

Another way to look at the phenomenon of positive return asymmetry is to examine the frequencies of extreme returns. Our final measure of return asymmetries is EXTRATIO, an “extreme-return ratio.” EXTRATIO for stock $i$ over the sample period is calculated as follows:

$$
\text { EXTRATIO }_{i}=\ln \left\{\frac{n_{\text {positive }}}{n_{\text {negative }}}\right\} \text {, }
$$

where $n_{\text {positive }}$ is the number of positive extreme return days and $n_{\text {negative }}$ is the number of negative extreme return days. A daily return, $R_{i \tau}$, is treated as a positive (negative) extreme return if $R_{i \tau}>+2 * \sigma_{i}\left(R_{i \tau}<-2 * \sigma_{i}\right)$, where $\sigma_{i}$ denotes the standard deviation of stock $i$. If the stock returns follow a normal distribution, EXTRATIO would be 0 . A larger positive (negative) value in EXTRATIO is associated with a stock that has a more right-skewed (left-skewed) return distribution. 
We use non-overlapping one-year observations, from January 1 to December 31, to compute our measures of return asymmetries. The choice of a one-year horizon to measure skewness is to make our skewness measure correspond to the availability of GDP per capita. In each year and for each firm in each country, we compute each measure of return asymmetries and report the average values for each country.

We present our measures of return asymmetries in the last three columns of Table 1 . The average (median) SKEW of daily returns in emerging markets is $0.26(0.25)$, while it is 0.14 (0.11) in developed markets. The magnitude of average SKEW in emerging markets is almost twice as large as that in developed markets. While average individual stock return skewness in both emerging and developed markets is positive, stocks in emerging markets show much more right-skewed return distributions than do those in developed markets. ${ }^{13}$ The results from the other two measures of return asymmetries show the same patterns, although the differences in the measures of return asymmetries between emerging markets and developed markets are less significant. More specifically, the average (median) VOLRATIO of daily returns is $0.15(0.14)$ in emerging markets, whereas it is $0.12(0.15)$ in developed markets. The average (median) EXTRATIO of daily returns is $0.30(0.32)$ in emerging markets, while it is $0.27(0.25)$ in developed markets.

\section{Measures of Corporate Governance}

To test our hypothesis, we need to have a measure for corporate governance. Since our main argument for return asymmetries is because of discretionary disclosures by managers and since earnings management is the most closely related to discretionary disclosures among those

\footnotetext{
${ }^{13}$ Most theories discussed in Section II are developed to explain the negative skewness found in the U.S. aggregate stock market returns. However, empirical evidence indicates that individual stock returns in the U.S. are positively skewed. For example, see Chen et al. (2001) for the evidence and explanations therein.
} 
corporate governance measures available, we use the earnings management index reported by Leuz et al. (2003) as our proxy for corporate governance, which we denote as $C G_{i t}$. The earnings management index is the aggregate score from four individual earnings management measures. The first individual measure is the country's median ratio of the firm-level standard deviations of operating income and operating cash flow. The second individual measure is the country's Spearman correlation between the change in accruals and the change in cash flow from operations. The third individual measure is the country's median ratio of the absolute value of accruals and the absolute value of the cash flow from operations. The fourth individual measure is the number of "small profits" divided by the number of "small losses" for each country. A higher earnings management index indicates a higher probability of earnings management or poorer corporate governance. The earnings management index ranges from 2.0 for the U.S. to 28.3 for Austria and Greece. $C G_{i t}$ is the same for all firms from the same country in all sample years.

To check the robustness of the measure of corporate governance, we also examine five alternative measures of corporate governance: (1) anti-director rights, (2) accounting standards, (3) corporate boards, (4) insider trading, and (5) stock return synchronicity. It is worth mentioning that the concepts for corporate governance are quite different among these different measures, although they are closely related. Earnings management, accounting standards, and the $\mathrm{R}^{2}$ are measures more related to information disclosure and processing, while anti-director rights, corporate boards, and insider trading are those more related to shareholder rights.

The anti-director rights index is taken from La Porta et al. (1998). La Porta et al. (1998) construct the anti-director rights index as the sum of the six rights measuring how strongly the legal system favors minority shareholders against controlling shareholders in the corporate 
decision-making process with the index ranging from 0 to 6 . A higher score on this index indicates greater respect for investor protection or better corporate governance. The accounting standards index is also taken from La Porta et al. (1998). The index is constructed by examining or rating companies' 1990 annual reports on their inclusion or omission of 90 items, suggesting a minimum score of 0 and a maximum score of 90 . These items fall into seven categories: general information, income statements, balance sheets, funds flow statements, accounting standards, stock data, and special items. The index ranges from 36 for Portugal to 83 for Sweden. A higher score of accounting standards suggests higher accounting report quantity/quality or better corporate governance.

The corporate board index is a score compiled by the Institute for Management Development (IMD). The higher the corporate board index score, the more effective the board or the better the corporate governance. The corporate board index ranges from 4.45 for Korea and 7.55 for Denmark and Finland. The insider trading index is a score also compiled by the IMD. The higher the insider trading index, the less likely there is insider trading or the better the corporate governance. The insider trading index ranges from 3.90 for Taiwan and 8.20 for Denmark. The stock return synchronicity is measured by the regression $\mathrm{R}^{2}$ taken from Morck et al. (2000). $\mathrm{R}^{2}$ is the explanatory power from the market model and is a proxy for informational inefficiency. A higher $\mathrm{R}^{2}$ is associated with a market being less informationally efficient or having poorer corporate governance. ${ }^{14}$ The $\mathrm{R}^{2}$ index ranges from 0.02 for the U.S. and 0.43 for Malaysia. Note that unlike other measures of corporate governance, the $\mathrm{R}^{2}$ index can be confounded by skewness as heteroskedasticity leads to higher correlations. As such, there may be an

\footnotetext{
${ }^{14}$ Durnev, Morck, and Young (2004) argue that corporate governance mechanisms depend on stock prices. Where stock prices are more informative, these mechanisms induce better corporate governance - which induces more efficient capital investment decisions. Their empirical evidence supports the hypothesis that more informative stock prices measured by $\mathrm{R}^{2}$ are associated with more efficient capital investment decisions.
} 
endogeneity in the index. As a result, one should be cautious when interpreting the results from the $\mathrm{R}^{2}$ index.

Panel A of Table 2 reports the scores for the six different measures of corporate governance for each country and Panel B of Table 2 reports the correlations among these corporate governance measures. The results from Panel A of Table 2 suggest that developed markets have better corporate governance than do emerging markets in all measures of corporate governance, except for anti-director rights. Panel B of Table 2 shows that correlations among these six measures of corporate governance have all the correct signs, although some of them are not statistically significant. The earnings management index is significantly negatively associated with the anti-director rights index, the accounting standard index, and the corporate board index, while it is significantly positively associated with stock return synchronicity. The accounting standards index is significantly positively correlated with the corporate board index. The corporate board index is significantly positively associated with the insider trading index, whereas it is significantly negatively correlated with stock return synchronicity. Finally, the insider trading index is significantly negatively correlated with stock return synchronicity.

\section{Controlling Variables}

We construct the following controlling variables for our empirical analysis. TURNOVER $R_{i t}$ is the average annualized daily turnover for stock $i$ in sample year $t$ assuming 254 trading days per year. CUMRET $T_{i t}$ is the cumulative return on stock $i$ measured over the same one-year period $t$. $L N S I Z E_{i t}$ is the average of the logarithm of market capitalization for stock $i$ over sample year $t$. Market capitalization is expressed in terms of U.S. dollars. $L E V E R_{i, t}$ is the leverage ratio measured as the book value of debt over total assets for stock $i$ in sample year $t$. $M T B_{i, t}$ is the 
market-to-book equity for stock $i$ in sample year $t$. Since we are dealing with international markets, we also include SIGMACUR $R_{i t}$ in our regressions, which is the standard deviation of daily currency returns in the country that stock $i$ belongs to over sample year $t$. SIGMACUR controls for the possible impact of currency fluctuations on skewness in stock market returns. Exchange rates are expressed in terms of local currencies per U.S. dollar. That is, a positive return on a currency suggests an appreciation in the currency and vice versa. $L N G D P_{i t}$ is the logarithm of GDP per capita in U.S. dollars for the country that stock $i$ belongs to in sample year $t$.

Panel A of Table 3 reports the summary statistics of our key variables. Each variable in this table is first computed for each year for each firm in each country and then the statistics are derived from these time series and cross-sectional observations. Our key variable, the corporate governance index, has a mean value of 16.06 . The average $S K E W$ value is 0.20 , suggesting that our sample firms are, on average, positively skewed. ${ }^{15}$ The average annual turnover ratio is 1.62 times, while the average cumulative past one-year return is -6.30 percent. The average leverage ratio ( $L E V E R)$ is 0.25 , whereas the average market-to-book equity ratio $(M T B)$ is 2.66 . Finally, the average daily currency volatility is 1.26 percent, which translates into an annual volatility of 20.08 percent.

Panel B of Table 3 reports the correlation coefficients among our key variables. SKEW is significantly negatively correlated with lagged GDP (LNGDP) and lagged firm-level market capitalization (LNSIZE). SKEW is significantly positively correlated with the country-level poor corporate governance index (CG), indicating support for the discretionary-disclosure hypothesis. The discretionary-disclosure hypothesis suggests that stock returns should be more positively

\footnotetext{
${ }^{15}$ Chen et al. (2001) also report a positive mean SKEW value of 0.262 for individual firms in the U.S. during the sample period from July 1962 to December 1998.
} 
skewed for firms with less market scrutiny or monitoring (i.e., small market capitalization or poor corporate governance). SKEW is significantly negatively correlated with lagged firm-level cumulative returns (CUMRET), a finding that supports the stochastic-bubble model. We also observe that SKEW is positively correlated with lagged turnover (TURNOVER) but it is not significant. SKEW is significantly positively correlated with lagged financial leverage (LEVER), while it is significantly negatively correlated with $M T B$. CG is significantly negatively correlated with $L N G D P$. Since GDP per capita is a broad indicator of the differences in wealth in each country, the data suggest that richer countries have better governance quality. It is therefore important to control for GDP per capita in our regression analysis.

While not reported, the three measures of return asymmetries, SKEW, VOLRATIO, and EXTRATIO, are all highly correlated with each other, although they use different approaches to measure return asymmetries. SKEW has a correlation coefficient of 0.78 with VOLRATIO, while VOLRATIO has a correlation coefficient of 0.58 with EXTRATIO. SKEW has the relatively smaller correlation coefficient of 0.41 with EXTRATIO.

In the next section, we discuss our regression model in explaining return asymmetries in general and develop an argument for the rationale for why return asymmetry is more positively pronounced in emerging markets.

\section{Empirical Results from Firm-Level Data}

\section{A. Results from Random-effects Regressions}

We employ the following regression model to explain skewness in the daily returns of individual stocks, using pooled data across time and firms: 


$$
\begin{aligned}
\text { SKEW }_{i, t+1}=a_{0} & +a_{1} \text { SKEW }_{i t}+a_{2} \text { SIGMACUR }_{i t}+a_{3} \text { TURNOVER }_{i t} \\
& +a_{4} \text { CUMRET }_{i t}+a_{5} \text { LNSIZE }_{i t}+a_{6} \text { LEVER }_{i t}+a_{7} \text { MTB }_{i t} \\
& +a_{8} \text { LNGDP }_{i t}+a_{9} \text { CG }_{i} \\
& +\sum_{j=1}^{21} b_{j} \text { Industry }_{i}^{j}+ \\
& +\sum_{k=1}^{8} c_{k} \text { Year }_{k}+e_{i, t+1},
\end{aligned}
$$

where all variables are defined in Section III. The currency volatility variable, SIGMACUR, is included, since $S K E W$ may be influenced by the fluctuation of exchange rates due to changes in a country's fundamentals. The prediction of the signs for the key regression coefficients is as follows. According to the difference-of-opinion model, we expect that the regression coefficient on TURNOVER, $a_{3}$, is negative. Based on the stochastic-bubble theory, we expect that the regression coefficient on CUMRET, $a_{4}$, is negative. Based on the leverage-effects hypothesis, we expect the regression coefficient on $L E V E R, a_{6}$, to be negative, while we expect it to be positive for the coefficient on MTB, $a_{7}{ }^{16}$ The leverage-effects hypothesis suggests that the leverage effect induces negative skewness. Based on the discretionary-disclosure hypothesis or the risksharing hypothesis, we predict that the regression coefficient on $C G, a_{9}$, is positive. Since a firm's market capitalization and a country's GDP per capita may be proxies for corporate governance at the firm level and at the country level, respectively, we expected $a_{6}$ and $a_{7}$ to be negative.

We also include industry dummies to control for the industry effect and year dummies to control for the year effect. We use the SIC codes provided by Datastream International to classify firms into 22 industries. Since our data are similar to those in La Porta et al. (2002) except that their data are cross-sectional data while ours are panel data, we follow them in estimating all regressions using country random effects. As argued by La Porta et al. (2002, p.

\footnotetext{
${ }^{16}$ Empirical evidence shows that the market-to-book equity ratio is negatively associated with leverage.
} 
1160), the natural alternative specification is fixed effects. However, fixed effects are not feasible in our setup given that there is no within-country variation in the corporate governance variables.

Table 4 presents our random-effects regression results using local-currency returns. Model (1) is our baseline specification. Model (1) includes the following explanatory variables: intercept, lagged variables of SKEW, currency return volatility (SIGMACUR), turnover (TURNOVER), cumulative return (CUMRET), firm size (LNSIZE), leverage (LEVER), and market-to-book equity (MTB). The result from Model (1) indicates that stocks that have larger market capitalization (LNSIZE) have lower positive skewness (SKEW). This result mirrors the findings of Chen et al. (2001) and Harvey and Siddique (2000) that skewness is more negative on average among large-cap firms in the U.S. We also find that negative skewness is most significant in stocks around the world that have experienced higher returns in the previous 12month period. This is consistent with the finding by Chen et al. (2001) in the U.S. market and it appears to support the stochastic-bubble theory. Finally, SKEW is significantly positively associated with leverage ( $L E V E R)$ and negatively associated with market-to-book equity (MTB), which are inconsistent with the leverage-effects hypothesis.

In Model (2), we add LNGDP to our baseline model. We find that LNGDP is significantly negative, while our baseline results remain unchanged. In Model (3), we add the poor corporate governance index $(C G)$ to our baseline regression model. The coefficient of interest in this case is $a_{9}$, which is also the focus of this paper. We find that $a_{9}$ is highly significant and positive, suggesting that positive skewness is most pronounced for firms in countries that have poor corporate governance. In Model (4), we add both $L N G D P$ and CG to our baseline model. We find that when both $L N G D P$ and CG are included in the regression, while the coefficient on 
$L N G D P$ is no longer significant, the coefficient on $C G$ remains highly significant. The result in Model (4) suggests that the positive relation between $C G$ and SKEW is robust to whether or not GDP per capita is included in the regression.

Since the unobserved effect in our panel data is unknown, we also conduct the pooled OLS regressions using cluster analysis as robustness checks. The main conclusions and the significance levels remain virtually the same, when standard errors are adjusted for heteroscedasticity and clustering at the firm level. When standard errors are adjusted for heteroscedasticity and clustering at the country level, although the significance levels on the CG coefficient estimates are weaker, they are still positive and significant at the one percent significance level. We also estimate regressions using year-by-year country random effects. The results show that the regression coefficient on corporate governance is statistically significant with the expected positive sign in seven out of nine years.

By looking at other controlling variables, we find that the regression coefficient on lagged SKEW is always positive and significant, suggesting the persistence of SKEW. The coefficient on currency return volatility (SIGMASUR) is positive and significant. This result suggests that higher currency volatility in the previous year leads to more positive skewness. This result is perhaps due to the Asian currency crisis and the Russian debt crisis. Many Asian stock markets recovered from the currency shock quickly.

\section{B. Random-effects Regression Results Using Alternative Measures of Corporate Governance}

Up to this point, we have shown that positive skewness is significantly higher in countries that rank poorly in terms of corporate governance measured by earnings management. However, it is still possible that the cross-country relation between skewness and corporate governance 
measured by earnings management could be due to chance. To examine the robustness of our results and in particular the measures of corporate governance, we use five alternative measures of corporate governance that represent different attributes of corporate governance to re-estimate our full model specification of Equation (4). The results are reported in Table 5. Corporate governance is measured by anti-directors rights in Model (1), by accounting standards in Model (2), by corporate boards in Model (3), by insider trading in Model (4), and by stock return synchronicity in Model (5). The random-effects regression results in Table 5 suggest that our main results that positive stock return skewness is negatively (positively) related to a good (poor) corporate governance index remain unchanged. That is, positive stock return skewness is most pronounced in firms from markets that have poor corporate governance regardless of the measures of corporate governance used. Although the significance levels for most other explanatory variables do not change much, some are reduced substantially when different measures of corporate governance are used. Previous one-year returns, firm size, and market-tobook equity are always highly significant and negatively associated with SKEW regardless of alternative measures of corporate governance. However, leverage becomes insignificant in all cases, while GDP per capita becomes significantly negative when corporate governance is measured by anti-director rights, accounting standards and corporate boards.

\section{Random-effects Regressions from Alternative Measures of Return Asymmetry and Alternative Model Specifications}

To check the sensitivity of our results to the choice of currency, we replicate the regression results in Table 4 based on U.S. dollar returns. The results from Model (1) in Table 6 show that our full model results from Table 4 do not change. More specifically, the regression coefficient on the poor corporate governance index is highly significant and positive. This suggests that 
stocks in markets with poor corporate governance have greater positive skewness than do stocks in markets with good corporate governance, regardless of the choice of currency in measuring the returns. The results of other regression coefficients remain the same.

To check the sensitivity of our results to the choice of the measure of skewness, we report results from alternative measures of return asymmetries. Models (2) and (3) use VOLRATIO and EXTRATIO as dependent variables, respectively. While the estimated coefficient on the poor corporate governance index $(C G)$ is still positive and statistically significant when EXTRATIO is used, it becomes negative although insignificant when VOLRATIO is used. Estimates of most other variables are also similar to those using $S K E W$, indicating that our results are robust to the measure of return asymmetries.

Although our evidence of a positive relation between positive stock return skewness and poor corporate governance may imply discretionary disclosure by managers at the country level, it is not a direct test at the firm level. To test our hypothesis of discretionary disclosure at the firm level directly, we need a measure for discretionary disclosure by managers. Since there is no direct measure for discretionary disclosure by managers, we use concentrated ownership as a proxy for discretionary disclosure by managers. If a firm's ownership is more concentrated, it is more likely that managers have more discretionary power to disclose information, which induces more positive skewness. To test this prediction, in Model (4), we include concentrated ownership $(O W N)$ in our SKEW regression. Concentrated ownership data are collected from Worldscope. Since not every firm in our sample has ownership data, the firm-years in Model (4) are reduced by one third. The result in Model (4) shows that concentrated ownership is significantly and positively correlated with $S K E W$, a result that supports our prediction. That is, firms with higher concentrated ownership have significantly higher positive skewness. In addition, the variable of 
interest, $C G$, is still significantly and positively correlated with $S K E W$, even when $O W N$ is included in the regression and the sample size is reduced substantially.

In their recent paper, Bris, Goetzmann, and Zhu (2003) investigated the impact of short-sales restrictions on stock return distributions. One might argue that in markets where short selling is either prohibited or not practiced, returns should display more positive skewness, while the frequency of extremely negative returns should be lower. Since our results could be driven by the short-sales restrictions that are popular in emerging markets, we add a short-sales dummy variable that takes the value of one if a country allows and practices short selling and zero otherwise. The information on short-sales restrictions is taken from Bris et al. (2003). The results from Model (5) show that even when we include the short-sales dummy, the corporate governance index variable and concentrated ownership are still highly significant and positive, while the short-sales dummy is not significant. ${ }^{17}$

Overall, based on the evidence presented in Tables 4 to 6 , we conclude that stocks in the markets with poor corporate governance are associated with greater positive skewness. Our results are robust to alternative measures of corporate governance, to a variety of regression specifications, and to alternative measures of return asymmetries. The evidence provides support for the discretionary-disclosure or risk-sharing hypothesis at the country level and underscores the importance of corporate governance in explaining cross-sectional differences in return asymmetries across countries. In addition, our results also support the discretionary-disclosure hypothesis at the firm level, when concentrated ownership is used as a proxy for managerial discretionary disclosure.

\footnotetext{
${ }^{17}$ Our evidence on the cross-country analysis using market returns is consistent with Bris et al (2003). They find little evidence that short-sales constraints reduce the negative skewness of market-level returns.
} 


\section{Results from the Frequencies of Extremely Negative Returns}

Our main explanation for skewness is the asymmetric release of information in poor corporate governance firms, a lot of information on good news, but limited information on bad news. However, bad news will be revealed eventually. This suggests that extremely negative rates of return could happen more often in firms or countries with poor corporate governance, as was found by Johnson et al. (2000). To test this hypothesis, we calculate the frequencies of extremely negative daily returns for the countries with good corporate governance versus the countries with poor corporate governance.

Two measures of corporate governance are used: earnings management and anti-director rights. Countries with an earnings management index above the median ( $>=18.3$ ) are classified as poor corporate governance countries, while those below the median $(<18.3)$ are classified as good corporate governance countries. Similarly, countries with an anti-director index below the median $(<3)$ are classified as poor corporate governance countries, while those above the median $(>=3)$ are classified as good corporate governance countries. We use four different cutoffs to measure extremely negative daily returns: $<-3 \%,<-5 \%,<-7 \%$, and $<-10 \%$. Consistent with the discretionary-disclosure hypothesis, the results in Table 7 suggest that extremely negative rates of return occur significantly more often in poor corporate governance countries than in good corporate governance countries.

\section{Regression Results using Aggregate Market Index Returns}

We now turn to explaining the cross-sectional skewness in the returns from aggregate stock markets for additional robustness checks. Table 8 reports the random-effects regression results from six different measures of corporate governance. Our results from aggregate stock market 
returns are consistent with those using firm-level return data. More specifically, negative skewness is more profound in stock markets that have better corporate governance. However, the significance level is reduced, probably because of reduced sample size. In particular, when corporate governance is measured by corporate boards or insider trading, the coefficient on corporate governance is no longer statistically significant. Consistent with our firm-level evidence, the coefficient on the prior 12-month returns is significantly negative for all six measures of corporate governance, which fits the stochastic-bubble theory. We also find that the coefficient on $L N G D P$ is significantly negative, consistent with some of the firm-level results.

\section{Summary and Conclusions}

In this paper, we use stock return data from across the world to explain the cross-sectional variation in return asymmetries. Using data from more than 14,000 firms in 38 countries around the world, we find that returns are more positively skewed for stocks in markets that have lower scores on the good corporate governance index. In addition, firms with more concentrated ownership also have greater positive skewness. Our results are robust to different measures of return asymmetries, to alternative measures of corporate governance, and to different model specifications. By using aggregate market data, we also find that stock markets in countries with poorer corporate governance are more positively skewed.

Our findings are consistent with the discretionary-disclosure hypothesis at both the country and firm levels. We argue that, in poorer corporate governance countries or in more concentrated ownership firms, managers have more discretionary power to disclose good news immediately, while releasing bad news slowly. This managerial behavior will consequently impart a degree of positive skewness to stock returns. Our results suggest that stock markets in more developed or 
well-governed countries are better processors of economic information than are stock markets in developing or poorly governed countries.

While our evidence is generally consistent with the risk-sharing hypothesis, one would need information on whether or not a firm belongs to a particular business group in order to test directly such an effect. Note that stock returns for firms belonging to the same business groups may be more positively skewed, since a negative shock would not be fully reflected in the stock returns of these firms due to the implicit guarantee of bailout. On the other hand, an equally negative shock would be fully reflected in the stock returns of non-business-group firms that do not have such a guarantee, imparting more negative skewness to the stock returns of these firms.

Once the information regarding a firm's affiliation with a business group is available, we can test the risk-sharing hypothesis by adding two interaction variables in Model (4) of our Table 4: (i) the business-group dummy multiplied by the financial distress dummy, and (ii) the nonbusiness-group dummy multiplied by the financial distress dummy, in addition to the businessgroup dummy. The risk-sharing hypothesis predicts that the coefficient on the business-group dummy will be positive. It further predicts that the interaction variable of the non-business-group dummy multiplied by the financial distress dummy will be negative and smaller than the interaction variable of the business-group dummy multiplied by the financial distress dummy. The results of our preliminary test of the risk-sharing hypothesis using Korean business group data are consistent with these predictions. We leave the test of the risk-sharing hypothesis using international data to a future study. 


\section{References}

Bae, Kee-Hong, Jun-Koo Kang, and Jin-Mo Kim. 2002. Tunneling or value added? Evidence from mergers by Korean business groups. Journal of Finance 57 (December): 2695-2740.

Ball, Ray, Ashok Robin, and Joanna S. Wu. 2003. Incentives versus standards: properties of accounting income in four East Asian countries. Journal of Accounting and Economics 36 (December): 235-270.

Bekaert, Geert, and Guojun Wu. 2000. Asymmetric volatility and risk in equity markets. Review of Financial Studies 13 (Spring): 1-42.

Black, Fischer. 1976. Studies of stock price volatility changes. Proceedings of the 1976 Meetings of the American Statistical Association, Business and Economical Statistics Section, pp. 177181.

Blanchard, Oliver J., and Mark W. Watson. 1982. Bubbles, rational expectations, and financial markets. In Crises in Economic and Financial Structure, ed. P. Wachtel. Lexington, MA: Lexington Books, pp. 295-315.

Bris, Arturo, William N. Goetzmann, and Ning Zhu. 2003. Efficiency and the bear: Short sales and markets around the world. Working paper no. 9466, National Bureau of Economic Research, Cambridge, MA.

Campbell, John Y., and Ludger Hentschel. 1992. No news is good news: An asymmetric model of changing volatility in stock returns. Journal of Financial Economics 31 (June): 281-318.

Chang, Sea Jin, and Jaebum Hong. 2000. Economic performance of group-affiliated companies in Korea: Intragroup resource sharing and internal business transactions. Academy of Management Journal 43 (June): 429-448.

Chen, Joseph, Harrison Hong, and Jeremy Stein. 2001. Forecasting crashes: Trading volume, past returns, and conditional skewness in stock prices. Journal of Financial Economics 61 (September): 345-381.

Christie, Andrew A. 1982. The stochastic behavior of common stock variances: Value, leverage and interest rate effects. Journal of Financial Economics 10 (December): 407-432.

Claessens, Stijn, Simon Djankov, Joseph P.H. Fan, and Larry H.P. Lang. 2002. Disentangling the incentive and entrenchment effects of large shareholdings. Journal of Finance 57 (December): 2741-2771.

Credit Lyonnais Securities Asia (CLSA). 2001. Saints \& Sinners: Who’s Got Religion?

Credit Lyonnais Securities Asia (CLSA). 2002. Make me Holy...But Not Yet! 
Damodaran, Aswath. 1987. Information bias: Measures and implications. Working paper, Stern School of Business, New York University.

Das, Sanjiv R. and Rangarajan K. Sundaram. 1999. Of smiles and smirks: A term structure perspective. Journal of Financial and Quantitative Analysis 34 (June): 211-239.

Demirgüç-Kunt, Asli, and Vojislav Maksimovic. 1998. Law, finance and firm growth. Journal of Finance 53 (December): 2107-2137.

Durnev, Art, Randall Morck, and Bernard Young. 2004. Value-enhancing capital budgeting and firm-specific stock return variation. Journal of Finance 59 (February): 65-105.

Fan, Joseph P.H., and T.J. Wong. 2002. Corporate ownership structure and the informativeness of accounting earnings in East Asia. Journal of Accounting and Economics 33 (August): 401426.

French, Kenneth R., G. William Schwert, and Robert F. Stambaugh. 1987. Expected stock returns and volatility. Journal of Financial Economics 19 (September): 3-29.

Friedman, Eric, Simon Johnson, and Todd Mitton. 2003. Propping and tunneling. Journal of Comparative Economics (December) 31: 732-750.

Friend, Irwin, and Randolph Westerfield. 1980. Co-skewness and capital asset pricing. Journal of Finance 35 (September): 897-914.

Harvey, Campbell R., and Akhtar Siddique. 2000. Conditional skewness in asset pricing tests. Journal of Finance 55 (June): 1263-1295.

Hong, Harrison, and Jeremy C. Stein. 2003. Differences of opinion, short-sales constraints and market crashes. Review of Financial Studies 16 (Summer): 487-525.

Hung, Mingyi. 2001. Accounting standards and value relevance of financial statements: An international analysis. Journal of Accounting and Economics 30 (December): 401-420.

Johnson, Simon, Peter Boone, Alasdair Breach, and Eric Friedman. 2000. Corporate governance in the Asian financial crisis. Journal of Financial Economics 58 (October-November): 141186.

Khanna, Tarun, and Yishay Yafeh. 2005. Business groups and risk sharing around the world. Journal of Business 78 (January): 301-340.

Kraus, Alan, and Robert Litzenberger. 1976. Skewness preference and the valuation of risk assets. Journal of Finance 31 (September): 1085-1100.

La Porta, Rafael, Florencio Lopez-de-Silanes, Andrei Shleifer, and Robert W. Vishny. 1997. Legal determinants of external finance. Journal of Finance 52 (July): 1131-1150. 
La Porta, Rafael, Florencio Lopez-de-Silanes, Andrei Shleifer, and Robert W. Vishny. 1998. Law and finance. Journal of Political Economy 106 (December): 1113-1155.

La Porta, Rafael, Florencio Lopez-de-Silanes, Andrei Shleifer, and Robert W. Vishny. 2000. Investor protection and corporate governance. Journal of Financial Economics 58 (OctoberNovember): 3-27.

La Porta, Rafael, Florencio Lopez-de-Silanes, Andrei Shleifer, and Robert W. Vishny. 2002. Investor protection and corporate valuation. Journal of Finance 57 (June): 1147-1170.

Luez, Christian, Dhanajay Nanda, and Peter D. Wysocki. 2003. Earnings management and investor protection: An international comparison. Journal of Financial Economics 69 (September): 505-527.

Mitton, Todd. 2002. A cross-firm analysis of the impact of corporate governance on the East Asia financial crisis. Journal of Financial Economics 64 (May): 215-241.

Morck, Randall, Bernard Yeung, and Wayne Yu. 2000. The information content of stock markets: Why do emerging markets have synchronous stock price movements? Journal of Financial Economics 58 (October-November): 215-260.

Pindyck, Robert S. 1984. Risk, inflation, and the stock market. American Economic Review 74 (June): 335-351.

Poterba, James M., and Lawrence H. Summer. 1986. The persistence of volatility and stock market fluctuations. American Economic Review 76 (December): 1142-1151.

Schwert, G. William. 1989. Why does stock market volatility change over time? Journal of Finance 44 (December): 1115-1153.

Sears, R. Stephen, and K.C. John Wei. 1985. Asset pricing, higher moments and the market risk premium: A note. Journal of Finance 40 (September): 1251-1253.

Standard \& Poor's. 2002. Transparency and Disclosure: Overview of Methodology and Study Results - United States, October 16. 
TABLE 1

Distributional Characteristics of Daily Stock Returns of Sample Firms for 38 Stock Markets

\begin{tabular}{|c|c|c|c|c|c|c|c|c|c|}
\hline Country & GDP & $\begin{array}{l}\text { Number } \\
\text { of firm }\end{array}$ & $\begin{array}{l}\text { Mean } \\
\text { return }\end{array}$ & $\begin{array}{l}\text { Standard } \\
\text { Deviation }\end{array}$ & $\begin{array}{c}1^{\text {st }} \\
\text { Quartile }\end{array}$ & $\begin{array}{c}3^{\text {rd }} \\
\text { Quartile }\end{array}$ & SKEW & $\begin{array}{c}\text { VOL- } \\
\text { RATIO }\end{array}$ & $\begin{array}{c}\text { EXT- } \\
\text { RATIO }\end{array}$ \\
\hline \multicolumn{10}{|c|}{ Panel A: Emerging markets } \\
\hline Argentina & 6,329 & 31 & 0.03 & 3.11 & -1.41 & 1.36 & 0.00 & 0.05 & 0.10 \\
\hline Brazil & 3,777 & 95 & 5.26 & 3.44 & -1.57 & 1.51 & 0.49 & 0.31 & 0.31 \\
\hline Chile & 4,930 & 42 & 0.98 & 1.82 & -0.74 & 0.64 & 0.23 & 0.11 & 0.30 \\
\hline Greece & 10,711 & 221 & -1.35 & 3.42 & -1.94 & 1.90 & 0.04 & 0.03 & 0.24 \\
\hline India & 439 & 238 & 4.68 & 3.46 & -1.75 & 1.58 & 0.29 & 0.20 & 0.37 \\
\hline Indonesia & 903 & 109 & -3.27 & 4.81 & -1.54 & 0.96 & 0.41 & -0.09 & 0.34 \\
\hline Korea & 10,438 & 702 & -4.52 & 4.07 & -2.10 & 1.79 & 0.17 & 0.07 & 0.34 \\
\hline Malaysia & 3,918 & 534 & -3.34 & 3.39 & -1.48 & 1.14 & 0.47 & 0.33 & 0.41 \\
\hline Pakistan & 439 & 31 & 8.00 & 3.04 & -1.26 & 1.24 & 0.21 & 0.28 & 0.32 \\
\hline Peru & 2,186 & 20 & -1.15 & 2.66 & -1.12 & 0.88 & 0.25 & 0.14 & 0.12 \\
\hline The Philippines & 994 & 68 & -8.98 & 3.81 & -1.64 & 1.05 & 0.20 & -0.21 & 0.41 \\
\hline Portugal & 10,812 & 47 & 0.09 & 2.21 & -0.95 & 0.79 & 0.49 & 0.26 & 0.27 \\
\hline South Africa & 3,018 & 249 & -1.08 & 3.60 & -1.19 & 1.05 & -0.02 & -0.07 & 0.17 \\
\hline Spain & 14,655 & 109 & 3.63 & 2.03 & -0.96 & 0.91 & 0.50 & 0.38 & 0.41 \\
\hline Taiwan & 12,876 & 433 & -3.36 & 2.96 & -1.78 & 1.58 & 0.13 & 0.12 & 0.23 \\
\hline Thailand & 2,199 & 204 & -0.28 & 3.51 & -1.60 & 1.36 & 0.38 & 0.26 & 0.39 \\
\hline Turkey & 2,671 & 147 & 12.08 & 4.35 & -2.15 & 2.19 & 0.26 & 0.33 & 0.32 \\
\hline Mean & 5,370 & 193 & 0.44 & 3.28 & -1.48 & 1.29 & 0.26 & 0.15 & 0.30 \\
\hline Median & 3,777 & 109 & -0.28 & 3.42 & -1.54 & 1.24 & 0.25 & 0.14 & 0.32 \\
\hline \multicolumn{10}{|c|}{ Panel B: Developed markets } \\
\hline Australia & 19,906 & 605 & 0.22 & 3.21 & -1.35 & 1.21 & 0.10 & 0.01 & 0.22 \\
\hline Austria & 25,714 & 51 & -0.68 & 1.96 & -0.81 & 0.76 & 0.06 & 0.03 & 0.07 \\
\hline Belgium & 23,949 & 70 & -1.30 & 2.21 & -1.01 & 0.92 & 0.11 & -0.01 & 0.15 \\
\hline Canada & 21,996 & 833 & -0.08 & 3.76 & -1.80 & 1.58 & 0.26 & 0.17 & 0.30 \\
\hline Denmark & 31,984 & 73 & -0.77 & 2.14 & -0.94 & 0.88 & -0.03 & 0.11 & 0.17 \\
\hline Finland & 24,195 & 79 & -1.52 & 2.83 & -1.31 & 1.17 & 0.24 & 0.23 & 0.25 \\
\hline France & 24,144 & 521 & -0.60 & 2.93 & -1.32 & 1.16 & 0.28 & 0.18 & 0.31 \\
\hline Germany & 24,231 & 331 & -10.75 & 3.67 & -1.81 & 1.40 & 0.33 & 0.08 & 0.22 \\
\hline Hong Kong & 24,317 & 407 & -3.66 & 3.72 & -1.49 & 1.17 & 0.02 & -0.01 & 0.37 \\
\hline Ireland & 27,429 & 22 & 1.69 & 3.15 & -1.36 & 1.28 & -0.11 & 0.15 & 0.23 \\
\hline Israel & 17,234 & 64 & -2.32 & 2.67 & -1.34 & 1.23 & -0.12 & 0.09 & 0.24 \\
\hline Italy & 20,016 & 209 & 0.11 & 2.39 & -1.24 & 1.06 & 0.51 & 0.33 & 0.53 \\
\hline Japan & 35,382 & 2,458 & -3.39 & 2.92 & -1.39 & 1.14 & 0.23 & 0.00 & 0.32 \\
\hline The Netherlands & 24,761 & 160 & -0.53 & 2.54 & -1.18 & 1.05 & 0.18 & 0.19 & 0.30 \\
\hline New Zealand & 15,001 & 65 & 3.34 & 2.05 & -0.82 & 0.79 & 0.11 & 0.15 & 0.20 \\
\hline Norway & 35,857 & 107 & -1.55 & 3.22 & -1.58 & 1.39 & 0.12 & 0.19 & 0.36 \\
\hline Singapore & 22,730 & 284 & -1.97 & 3.44 & -1.51 & 1.18 & 0.28 & 0.06 & 0.41 \\
\hline Sweden & 27,325 & 276 & -1.94 & 3.19 & -1.59 & 1.35 & 0.33 & 0.19 & 0.33 \\
\hline Switzerland & 37,770 & 125 & 0.89 & 2.42 & -1.11 & 1.06 & 0.07 & 0.22 & 0.18 \\
\hline U.K. & 23,226 & 1,128 & -1.45 & 2.57 & -0.63 & 0.48 & -0.15 & -0.01 & 0.24 \\
\hline U.S. & 32,397 & 2,988 & 1.74 & 3.75 & -1.85 & 1.74 & 0.09 & 0.15 & 0.28 \\
\hline Mean & 25,693 & 517 & -1.17 & 2.89 & -1.31 & 1.14 & 0.14 & 0.12 & 0.27 \\
\hline Median & 24,231 & 209 & -0.77 & 2.92 & -1.34 & 1.17 & 0.11 & 0.15 & 0.25 \\
\hline
\end{tabular}


NOTE:-This table presents distributional characteristics of the daily local-currency returns for 14,136 individual stocks from 38 sample countries during the period 1995-2003. In each year and for each firm in each country, we compute sample statistics (mean, standard deviation, $1^{\text {st }}$ quartile, $3^{\text {rd }}$ quartile, skewness, volatility ratio, and extreme return ratio) and report the average of a sample statistic for each country. The sample countries are partitioned into two subgroups, emerging markets (Panel A) and developed markets (Panel B), by a cutoff point of an average GDP per capita of US $\$ 15,000$. The last three columns present three measures of return asymmetries: (1) skewness (SKEW), (2) volatility ratio (VOLRATIO), and (3) extreme return ratio (EXTRATIO). Skewness is measured as: $S K E W_{i, t}=\left[(n(n-1))^{3 / 2} \sum_{\tau=1}^{n} R_{i \tau, t}^{3}\right] \div\left[(n-1)(n-2)\left(\sum_{\tau=1}^{n} R_{i \tau, t}^{2}\right)^{3 / 2}\right]$, where $R_{i \tau}$ represents the daily return with dividends for stock $i$ on day $\tau$ and $n$ is the number of observations on daily returns during the sample year, $t$. Daily returns are computed as $\ln \left[\left(P_{i \tau}+D_{i \tau}\right) / P_{i \tau-1}\right]$, where $P_{i \tau}$ is the stock price of stock $i$ at the close of day $\tau$ and $D_{i \tau}$ is the dividend. The volatility ratio is measured as: VOLRATIO $\operatorname{VO}_{i, t}=$ $\ln \left\{\left(n_{d}-1\right) \sum_{\tau \in U P} R_{i \tau, t}^{2} \div\left(n_{u}-1\right) \sum_{\tau \in D O W N} R_{i \tau, t}^{2}\right\}$, where $n_{u}$ and $n_{d}$ are the number of up and down days, respectively. An up (a down) day is a day on which the stock index return is above (below) the sample mean during the sample year, $t$. The extreme return ratio (EXTRATIO) is measured as the log of the ratio of the number of positive extreme return days to the number of negative extreme return days. A daily return, $R_{i \tau}$, is treated as a positive (negative) extreme return if $R_{i \tau}>2 * \sigma_{i}\left(R_{i \tau}<-2 * \sigma_{i}\right)$, where $\sigma_{i}$ denotes the standard deviation of returns of stock $i$. The data are drawn from Datastream International. The mean is in basis points. Standard deviation, $1^{\text {st }}$ quartile, and $3^{\text {rd }}$ quartile are in percent. 
TABLE 2

Corporate Governance Variables

Panel A: Corporate governance indices

\begin{tabular}{|c|c|c|c|c|c|c|}
\hline Country & $\begin{array}{c}\text { Earnings } \\
\text { management }\end{array}$ & $\begin{array}{l}\text { Anti-director } \\
\text { rights }\end{array}$ & $\begin{array}{c}\text { Accounting } \\
\text { standards }\end{array}$ & $\begin{array}{c}\text { Corporate } \\
\text { boards }\end{array}$ & $\begin{array}{l}\text { Insider } \\
\text { trading }\end{array}$ & $\begin{array}{c}\mathrm{R}^{2} \text { from Morck } \\
\text { et al. (2000) }\end{array}$ \\
\hline \multicolumn{7}{|c|}{ Emerging markets } \\
\hline Argentina & - & 4.00 & 45.00 & 4.81 & 5.05 & - \\
\hline Brazil & - & 3.00 & 54.00 & 5.71 & 5.85 & 0.16 \\
\hline Chile & - & 5.00 & 52.00 & 7.18 & 6.15 & 0.21 \\
\hline Greece & 28.30 & 2.00 & 55.00 & 5.07 & 4.20 & 0.19 \\
\hline India & 19.10 & 5.00 & 57.00 & 4.77 & 4.23 & 0.19 \\
\hline Indonesia & 18.30 & 2.00 & - & 5.73 & 4.40 & 0.14 \\
\hline Korea & 26.80 & 2.00 & 62.00 & 4.45 & 4.09 & 0.17 \\
\hline Malaysia & 14.80 & 4.00 & 76.00 & 5.22 & 4.25 & 0.43 \\
\hline Pakistan & 17.80 & 5.00 & - & - & - & 0.18 \\
\hline Peru & - & 3.00 & - & - & - & 0.29 \\
\hline The Philippines & 8.80 & 3.00 & 65.00 & 5.10 & 3.37 & 0.16 \\
\hline Portugal & 25.10 & 3.00 & 36.00 & 5.74 & 5.96 & 0.07 \\
\hline South Africa & 5.60 & 5.00 & 70.00 & 6.52 & 5.27 & 0.20 \\
\hline Spain & 18.60 & 4.00 & 64.00 & 6.06 & 5.91 & 0.19 \\
\hline Taiwan & 22.50 & 3.00 & 65.00 & 6.20 & 3.90 & 0.41 \\
\hline Thailand & 18.30 & 2.00 & 64.00 & 5.63 & 4.51 & 0.27 \\
\hline Turkey & - & 2.00 & 51.00 & 5.18 & 3.93 & 0.39 \\
\hline Mean & 18.67 & 3.35 & 58.28 & 5.56 & 4.74 & 0.23 \\
\hline Median & 18.45 & 3.00 & 59.50 & 5.63 & 4.40 & 0.19 \\
\hline \multicolumn{7}{|c|}{ Developed markets } \\
\hline Australia & 4.80 & 4.00 & 75.00 & 6.84 & 7.48 & 0.06 \\
\hline Austria & 28.30 & 2.00 & 54.00 & 6.64 & 5.88 & 0.09 \\
\hline Belgium & 19.50 & 0.00 & 61.00 & 5.88 & 6.09 & 0.15 \\
\hline Canada & 5.30 & 5.00 & 74.00 & 6.98 & 7.19 & 0.06 \\
\hline Denmark & 16.00 & 2.00 & 62.00 & 7.55 & 8.20 & 0.08 \\
\hline Finland & 12.00 & 3.00 & 77.00 & 7.55 & 7.85 & 0.14 \\
\hline France & 13.50 & 3.00 & 69.00 & 5.67 & 5.82 & 0.08 \\
\hline Germany & 21.50 & 1.00 & 62.00 & 6.29 & 6.96 & 0.11 \\
\hline Hong Kong & 19.50 & 5.00 & 69.00 & 6.50 & 6.19 & 0.15 \\
\hline Ireland & 5.10 & 4.00 & - & 6.64 & 7.16 & 0.06 \\
\hline Israel & - & 3.00 & 64.00 & 6.41 & 6.47 & - \\
\hline Italy & 24.80 & 1.00 & 62.00 & 5.41 & 4.95 & 0.18 \\
\hline Japan & 20.50 & 4.00 & 65.00 & 4.88 & 6.16 & 0.23 \\
\hline The Netherlands & 16.50 & 2.00 & 64.00 & 7.44 & 7.25 & 0.10 \\
\hline New Zealand & - & 4.00 & 70.00 & 7.28 & 6.42 & 0.06 \\
\hline
\end{tabular}




$\begin{array}{lrrrrrrr}\text { Norway } & 5.80 & 4.00 & 74.00 & 6.04 & 4.37 & 0.12 \\ \text { Singapore } & 21.60 & 4.00 & 78.00 & 7.19 & 7.61 & 0.19 & 0.14 \\ \text { Sweden } & 6.80 & 3.00 & 83.00 & 7.27 & 6.42 & - \\ \text { Switzerland } & 22.00 & 2.00 & 68.00 & 6.39 & 6.98 & 6.53 & 0.06 \\ \text { U.K. } & 7.00 & 5.00 & 78.00 & 6.34 & 6.38 & 6.55 & 0.02 \\ \text { U.S. } & 2.00 & 5.00 & 71.00 & & & \mathbf{0 . 1 1} \\ \text { Mean } & & & & \mathbf{6 . 6 0} & \mathbf{6 . 5 5} & \mathbf{6 . 1 0} \\ \text { Median } & \mathbf{1 4 . 3 4} & \mathbf{3 . 1 4} & \mathbf{6 9 . 0 0} & \mathbf{6 9 . 0 0} & \mathbf{6 . 5 0} & & \end{array}$

$\underline{\text { Panel B: Correlations among corporate governance indices }}$

\begin{tabular}{|c|c|c|c|c|c|c|}
\hline & $\begin{array}{c}\text { Earnings } \\
\text { management }\end{array}$ & $\begin{array}{l}\text { Anti-director } \\
\text { rights }\end{array}$ & $\begin{array}{l}\text { Accounting } \\
\text { standards }\end{array}$ & $\begin{array}{c}\text { Corporate } \\
\text { boards }\end{array}$ & $\begin{array}{l}\text { Insider } \\
\text { trading }\end{array}$ & $\begin{array}{l}\mathrm{R}^{2} \text { from Morck } \\
\text { et al. (2000) }\end{array}$ \\
\hline $\begin{array}{l}\text { Earnings } \\
\text { management }\end{array}$ & 1.000 & & & & & \\
\hline $\begin{array}{l}\text { Anti-director } \\
\text { rights }\end{array}$ & $\begin{array}{l}-0.490 \\
(0.01)\end{array}$ & 1.000 & & & & \\
\hline $\begin{array}{l}\text { Accounting } \\
\text { standards }\end{array}$ & $\begin{array}{l}-0.541 \\
(0.00)\end{array}$ & $\begin{array}{r}0.216 \\
(0.22)\end{array}$ & 1.000 & & & \\
\hline $\begin{array}{l}\text { Corporate } \\
\text { boards }\end{array}$ & $\begin{array}{l}-0.354 \\
(0.05)\end{array}$ & $\begin{array}{r}0.140 \\
(0.42)\end{array}$ & $\begin{array}{r}0.407 \\
(0.02)\end{array}$ & 1.000 & & \\
\hline $\begin{array}{l}\text { Insider } \\
\text { trading }\end{array}$ & $\begin{array}{l}-0.230 \\
(0.22)\end{array}$ & $\begin{array}{c}0.079 \\
(0.65)\end{array}$ & $\begin{array}{l}0.255 \\
(0.15)\end{array}$ & $\begin{array}{c}0.758 \\
(0.00)\end{array}$ & 1.000 & \\
\hline $\begin{array}{l}\mathrm{R}^{2} \text { from Morck } \\
\text { et al. (2000) }\end{array}$ & $\begin{array}{l}0.596 \\
(0.00)\end{array}$ & $\begin{array}{l}-0.153 \\
(0.38)\end{array}$ & $\begin{array}{l}-0.105 \\
(0.57)\end{array}$ & $\begin{array}{l}-0.428 \\
(0.01)\end{array}$ & $\begin{array}{l}-0.589 \\
(0.00)\end{array}$ & 1.000 \\
\hline
\end{tabular}

NOTE:- This table presents various corporate governance variables used for our 38 sample countries. The earnings management index (with a higher score indicating more earnings management) is the aggregate earnings management score reported by Leuz et al. (2003); the anti-director rights (with a higher score on this index indicating better protection of shareholder rights) index is taken from La Porta et al. (1998); the accounting standards index (with a higher score indicating higher accounting quality) is also taken from La Porta et al. (1998); the corporate boards index (with a higher score indicating more effective boards) is a score compiled by the Institute for Management Development International (IMD); the insider trading index (with a higher score indicating less insider trading) is a score also compiled by IMD; $\mathrm{R}^{2}$ is a measure of stock return synchronicity and is taken from Morck et al. (2000). $\mathrm{R}^{2}$ is the explanatory power from the market model and is a proxy for the informational efficiency with a higher $\mathrm{R}^{2}$ being less informationally efficient. 
TABLE 3

Summary Statistics of Variables

Panel A: Summary statistics

\begin{tabular}{|c|c|c|c|c|c|c|c|c|c|c|c|}
\hline & $C G_{t}$ & $S K E W_{t}$ & $\begin{array}{c}V O L- \\
\text { RATIO }_{t}\end{array}$ & $\begin{array}{c}E X T- \\
R A T I O\end{array}$ & $\begin{array}{l}\text { TURN- } \\
\text { OVER }\end{array}$ & $\begin{array}{l}C U M- \\
R E T_{t}\end{array}$ & $L_{N S I Z E_{t}}$ & $L E V E R_{t}$ & $M T B_{t}$ & $\begin{array}{c}\text { SIGMA- } \\
\text { CUR }_{t}\end{array}$ & $L N G D P_{t}$ \\
\hline \multicolumn{12}{|l|}{ All sample countries } \\
\hline Mean & 16.06 & 0.20 & 0.13 & 0.28 & 1.62 & -6.30 & 6.86 & 0.25 & 2.66 & 1.26 & 9.22 \\
\hline Median & 18.30 & 0.20 & 0.14 & 0.30 & 0.70 & -7.59 & 5.86 & 0.25 & 2.50 & 0.76 & 9.82 \\
\hline Standard deviation & 7.75 & 0.18 & 0.13 & 0.10 & 2.54 & 12.75 & 2.68 & 0.05 & 0.97 & 2.04 & 1.27 \\
\hline $1^{\text {st }}$ Quartile & 7.00 & 0.07 & 0.03 & 0.22 & 0.50 & -11.43 & 5.11 & 0.21 & 1.99 & 0.46 & 8.27 \\
\hline $3^{\text {rd }}$ Quartile & 21.60 & 0.29 & 0.22 & 0.34 & 1.22 & -1.48 & 7.46 & 0.28 & 3.06 & 0.99 & 10.10 \\
\hline
\end{tabular}

Panel B: Correlations among variables

\begin{tabular}{|c|c|c|c|c|c|c|c|}
\hline & $S K E W_{t+1}$ & $S K E W_{t}$ & TURNOVER $_{t}$ & CUMRET $_{t}$ & $L N S I Z E_{t}$ & $L E V E R_{t}$ & $M_{T} B_{t}$ \\
\hline$\overline{S K E W_{t+1}}$ & 1.000 & & & & & & \\
\hline$S K E W_{t}$ & $\begin{array}{c}0.055 \\
(0.00)\end{array}$ & 1.000 & & & & & \\
\hline TURNOVER $R_{t}$ & $\begin{array}{c}0.006 \\
(0.14)\end{array}$ & $\begin{array}{l}-0.001 \\
(0.78)\end{array}$ & 1.000 & & & & \\
\hline$C U M R E T_{t}$ & $\begin{array}{l}-0.062 \\
(0.00)\end{array}$ & $\begin{array}{c}0.384 \\
(0.00)\end{array}$ & $\begin{array}{c}0.002 \\
(0.65)\end{array}$ & 1.000 & & & \\
\hline LNSIZE $_{t}$ & $\begin{array}{l}-0.048 \\
(0.00)\end{array}$ & $\begin{array}{c}0.016 \\
(0.00)\end{array}$ & $\begin{array}{c}0.013 \\
(0.00)\end{array}$ & $\begin{array}{c}0.146 \\
(0.00)\end{array}$ & 1.000 & & \\
\hline LEVER $_{t}$ & $\begin{array}{r}0.011 \\
(0.00)\end{array}$ & $\begin{array}{l}-0.017 \\
(0.00)\end{array}$ & $\begin{array}{c}0.014 \\
(0.00)\end{array}$ & $\begin{array}{l}-0.064 \\
(0.00)\end{array}$ & $\begin{array}{c}0.176 \\
(0.00)\end{array}$ & 1.000 & \\
\hline$M T B_{t}$ & $\begin{array}{l}-0.054 \\
(0.00)\end{array}$ & $\begin{array}{c}0.072 \\
(0.00)\end{array}$ & $\begin{array}{c}0.008 \\
(0.04)\end{array}$ & $\begin{array}{c}0.215 \\
(0.00)\end{array}$ & $\begin{array}{c}0.001 \\
(0.72)\end{array}$ & $\begin{array}{l}-0.031 \\
(0.00)\end{array}$ & 1.000 \\
\hline
\end{tabular}




\begin{tabular}{|c|c|c|c|c|c|c|c|c|c|c|}
\hline$S_{S I G M A C U R_{t}}$ & $\begin{array}{c}0.036 \\
(0.00)\end{array}$ & $\begin{array}{l}-0.000 \\
(0.98)\end{array}$ & $\begin{array}{r}0.002 \\
(0.68)\end{array}$ & $\begin{array}{l}-0.030 \\
(0.00)\end{array}$ & $\begin{array}{c}0.203 \\
(0.00)\end{array}$ & $\begin{array}{c}0.107 \\
(0.00)\end{array}$ & $\begin{array}{l}-0.029 \\
(0.00)\end{array}$ & 1.000 & & \\
\hline$L N G D P_{t}$ & $\begin{array}{l}-0.038 \\
(0.00)\end{array}$ & $\begin{array}{l}-0.025 \\
(0.00)\end{array}$ & $\begin{array}{l}-0.035 \\
(0.00)\end{array}$ & $\begin{array}{c}0.006 \\
(0.10)\end{array}$ & $\begin{array}{l}-0.096 \\
(0.00)\end{array}$ & $\begin{array}{l}-0.008 \\
(0.00)\end{array}$ & $\begin{array}{c}0.042 \\
(0.00)\end{array}$ & $\begin{array}{l}-0.198 \\
(0.00)\end{array}$ & 1.000 & \\
\hline$C G_{t}$ & $\begin{array}{c}0.059 \\
(0.00)\end{array}$ & $\begin{array}{r}0.066 \\
(0.00)\end{array}$ & $\begin{array}{c}0.009 \\
(0.02)\end{array}$ & $\begin{array}{l}-0.037 \\
(0.00)\end{array}$ & $\begin{array}{r}0.489 \\
(0.00)\end{array}$ & $\begin{array}{r}0.171 \\
(0.00)\end{array}$ & $\begin{array}{l}-0.129 \\
(0.00)\end{array}$ & $\begin{array}{r}0.202 \\
(0.00)\end{array}$ & $\begin{array}{l}-0.272 \\
(0.00)\end{array}$ & 1.000 \\
\hline
\end{tabular}

NOTE:-This table presents summary statistics of the variables used in the empirical analysis. The corporate governance index $\left(C G_{t}\right)$ is the earnings management index (with a higher score indicating more earnings management) and is the aggregate earnings management score reported by Leuz et al. (2003). $S K E W_{t}, V O L R A T I O O_{t}$ and EXTRATIO ${ }_{t}$ are defined in Table 1 . All variables are obtained by using returns in the one-year period for each sample firm in each sample country. Thus, for each sample firm in each sample country, nine yearly observations are obtained for each variable. Turnover ${ }_{t}\left(T U R N O V E R_{t}\right)$ is the average daily turnover in sample year $t$. Cumulative return ${ }_{t}\left(C U M R E T_{t}\right)$ is the cumulative return over sample year $t . L N S I Z E_{t}$ is the average (of the logarithm of) market capitalization (in U.S. dollars) in sample year $t . L E V E R_{t}$ is the leverage ratio measured as the book value of debt over total assets in sample year $t$. $M T B_{t}$ is the market-to-book equity in sample year $t$. Currency volatility $\left(S I G M A C U R_{t}\right)$ is the standard deviation of daily currency returns in sample year $t$. $L N G D P_{t}$ is the (logarithm of) GDP per capita (in U.S. dollars) in sample year $t$. Panel A reports means, medians, standard deviations, the $1^{\text {st }}$ quartiles, and the $3^{\text {rd }}$ quartiles. Panel B reports the correlations. 
TABLE 4

Random-effects Regressions for Conditional Skewness on the Corporate Governance Index

\begin{tabular}{lcccc}
\hline Independent variables & $(1)$ & $(2)$ & $(3)$ & $(4)$ \\
\hline Intercept & 0.285 & 0.690 & 0.224 & 0.295 \\
& $(0.022)$ & $(0.058)$ & $(0.024)$ & $(0.062)$ \\
Skewness & 0.091 & 0.091 & 0.086 & 0.086 \\
$\left(S K E W_{i, t}\right)$ & $(0.004)$ & $(0.004)$ & $(0.004)$ & $(0.004)$ \\
Currency return volatility & 0.034 & 0.030 & 0.023 & 0.022 \\
(SIGMACUR $)_{t}$ & $(0.004)$ & $(0.004)$ & $(0.004)$ & $(0.004)$ \\
Trading volume & 0.001 & 0.001 & 0.001 & 0.001 \\
$\left(\right.$ TURNOVER $\left.R_{i, t}\right)$ & $(0.001)$ & $(0.001)$ & $(0.001)$ & $(0.001)$ \\
Cumulative return & -0.160 & -0.160 & -0.146 & -0.146 \\
$\left(\right.$ CUMRET $\left.T_{i, t}\right)$ & $(0.008)$ & $(0.008)$ & $(0.008)$ & $(0.008)$ \\
Firm size & -0.019 & -0.020 & -0.041 & -0.040 \\
$\left(L N S I Z E_{i, t}\right)$ & $(0.002)$ & $(0.002)$ & $(0.002)$ & $(0.002)$ \\
Leverage & 0.051 & 0.046 & 0.047 & 0.046 \\
$\left(L E V E R_{i, t}\right)$ & $(0.025)$ & $(0.025)$ & $(0.025)$ & $(0.025)$ \\
Market-to-book & -0.011 & -0.011 & -0.009 & -0.009 \\
$\left(M T B_{i, t}\right)$ & $(0.001)$ & $(0.001)$ & $(0.001)$ & $(0.001)$ \\
GDP per capita & & -0.040 & & -0.007 \\
$\left(L N G D P_{i, t}\right)$ & & $(0.005)$ & & $(0.006)$ \\
Corporate governance index \\
$($ CG)
\end{tabular}

NOTE:-This table presents the results of random-effects regressions to explain return asymmetries across firms and across countries. The dependent variable is $S K E W_{i, t+1}$, the coefficient of skewness for stock $i$ in year $t+1$, that is computed using daily returns from each sample firm in each sample country. SIGMACUR $R_{t}$ is the currency volatility measured as the standard deviation of daily currency returns for the country that stock $i$ belongs to in year $t$. TURNOVER $R_{i, t}$ is the average daily turnover for stock $i$ in year $t$. CUMRET $T_{i, t}$ is the cumulative return for stock $i$ in year $t$. LNSIZE $_{\text {it }}$ is the average of the logarithm of market capitalization (in U.S. dollars) for stock $i$ in year $t$. $L E V E R_{i, t}$ is the leverage ratio measured as the book value of debt over total assets for stock $i$ in year $t . M T B_{i, t}$ is the market-to-book equity for stock $i$ in year $t . L N G D P_{i, t}$ is the logarithm of GDP per capita (in U.S. dollars) for the country that stock $i$ belongs to in year $t$. The corporate governance index $(C G)$ is the earnings management index and is the aggregate earnings management score reported by Leuz et al. (2003). A higher score on the index indicates a higher probability of earnings management. Standard errors are shown in parentheses. 
TABLE 5

Random-effects Regressions: Alternative Corporate Governance Indices

\begin{tabular}{|c|c|c|c|c|c|}
\hline Independent variables & $\begin{array}{l}\text { Shareholder } \\
\text { rights } \\
\text { (1) }\end{array}$ & $\begin{array}{l}\text { Accounting } \\
\text { standards } \\
\text { (2) }\end{array}$ & $\begin{array}{l}\text { Corporate } \\
\text { boards } \\
\text { (3) }\end{array}$ & $\begin{array}{l}\text { Insider } \\
\text { trading } \\
\text { (4) }\end{array}$ & $\begin{array}{l}\text { R2 from } \\
\text { Morck et al. } \\
\text { (5) }\end{array}$ \\
\hline Intercept & $\begin{array}{c}0.834 \\
(0.061)\end{array}$ & $\begin{array}{l}2.476 \\
(0.230)\end{array}$ & $\begin{array}{l}1.820 \\
(0.093)\end{array}$ & $\begin{array}{c}0.827 \\
(0.062)\end{array}$ & $\begin{array}{c}0.719 \\
(0.058)\end{array}$ \\
\hline $\begin{array}{l}\text { Skewness } \\
\left(S K E W_{i, t}\right)\end{array}$ & $\begin{array}{l}0.090 \\
(0.004)\end{array}$ & $\begin{array}{c}0.091 \\
(0.004)\end{array}$ & $\begin{array}{c}0.086 \\
(0.004)\end{array}$ & $\begin{array}{c}0.090 \\
(0.004)\end{array}$ & $\begin{array}{c}0.080 \\
(0.004)\end{array}$ \\
\hline $\begin{array}{l}\text { Currency return volatility } \\
\left(\text { SIGMACUR }_{t}\right)\end{array}$ & $\begin{array}{l}0.026 \\
(0.004)\end{array}$ & $\begin{array}{c}0.052 \\
(0.006)\end{array}$ & $\begin{array}{c}0.029 \\
(0.004)\end{array}$ & $\begin{array}{c}0.031 \\
(0.004)\end{array}$ & $\begin{array}{c}0.029 \\
(0.004)\end{array}$ \\
\hline $\begin{array}{l}\text { Trading volume } \\
\left(T U R N O V E R_{i, t}\right)\end{array}$ & $\begin{array}{c}0.001 \\
(0.000)\end{array}$ & $\begin{array}{c}0.001 \\
(0.001)\end{array}$ & $\begin{array}{c}0.001 \\
(0.000)\end{array}$ & $\begin{array}{c}0.001 \\
(0.000)\end{array}$ & $\begin{array}{c}0.001 \\
(0.000)\end{array}$ \\
\hline $\begin{array}{l}\text { Cumulative return } \\
\left(C U M R E T_{i, t}\right)\end{array}$ & $\begin{array}{l}-0.159 \\
(0.008)\end{array}$ & $\begin{array}{l}-0.158 \\
(0.008)\end{array}$ & $\begin{array}{l}-0.145 \\
(0.008)\end{array}$ & $\begin{array}{l}-0.157 \\
(0.008)\end{array}$ & $\begin{array}{l}-0.137 \\
(0.008)\end{array}$ \\
\hline $\begin{array}{l}\text { Firm size } \\
\left(L N S I Z E_{i, t}\right)\end{array}$ & $\begin{array}{l}-0.021 \\
(0.002)\end{array}$ & $\begin{array}{l}-0.027 \\
(0.002)\end{array}$ & $\begin{array}{l}-0.037 \\
(0.002)\end{array}$ & $\begin{array}{l}-0.023 \\
(0.002)\end{array}$ & $\begin{array}{l}-0.038 \\
(0.002)\end{array}$ \\
\hline $\begin{array}{l}\text { Leverage } \\
\left(L E V E R_{i, t}\right)\end{array}$ & $\begin{array}{c}0.035 \\
(0.025)\end{array}$ & $\begin{array}{c}0.033 \\
(0.025)\end{array}$ & $\begin{array}{c}0.009 \\
(0.025)\end{array}$ & $\begin{array}{c}0.038 \\
(0.025)\end{array}$ & $\begin{array}{c}0.034 \\
(0.025)\end{array}$ \\
\hline $\begin{array}{l}\text { Market-to-book } \\
\left(M^{\prime} B_{i, t}\right)\end{array}$ & $\begin{array}{l}-0.010 \\
(0.001)\end{array}$ & $\begin{array}{l}-0.010 \\
(0.001)\end{array}$ & $\begin{array}{l}-0.009 \\
(0.001)\end{array}$ & $\begin{array}{l}-0.010 \\
(0.001)\end{array}$ & $\begin{array}{l}-0.009 \\
(0.001)\end{array}$ \\
\hline $\begin{array}{l}\text { GDP per capita } \\
\left(L N G D P_{i, t}\right)\end{array}$ & $\begin{array}{l}-0.033 \\
(0.005)\end{array}$ & $\begin{array}{l}-0.026 \\
(0.006)\end{array}$ & $\begin{array}{l}-0.028 \\
(0.005)\end{array}$ & $\begin{array}{l}-0.010 \\
(0.007)\end{array}$ & $\begin{array}{c}0.001 \\
(0.006)\end{array}$ \\
\hline $\begin{array}{l}\text { Corporate governance index } \\
\text { (CG) }\end{array}$ & $\begin{array}{l}-0.119 \\
(0.017)\end{array}$ & $\begin{array}{l}-0.443 \\
(0.055)\end{array}$ & $\begin{array}{l}-0.625 \\
(0.041)\end{array}$ & $\begin{array}{l}-0.220 \\
(0.036)\end{array}$ & $\begin{array}{c}0.116 \\
(0.006)\end{array}$ \\
\hline Time dummy variables & Yes & Yes & Yes & Yes & Yes \\
\hline Industry dummy variables & Yes & Yes & Yes & Yes & Yes \\
\hline$R^{2}$ & 0.033 & 0.033 & 0.035 & 0.033 & 0.037 \\
\hline No. of observations & 69,546 & 68,940 & 69,359 & 69,359 & 68,569 \\
\hline
\end{tabular}

NOTE:- This table presents the results of random-effects regressions to explain return asymmetries across firms using alternative measures of corporate governance. All variables are as defined in Table 3. The corporate governance index includes: (1) anti-director rights, (2) accounting standards, (3) corporate boards, (4) insider trading, and (5) the $\mathrm{R}^{2}$ measure. The anti-director rights index (with a higher score indicating a better protection of shareholder rights) is taken from La Porta et al. (1998); the accounting standard index (with a high score indicating higher accounting quality) is taken from La Porta et al. (1998); the corporate boards index (with a higher score indicating more effective boards) is the score compiled by IMD; the insider trading index (with a higher score indicating less insider trading) is a score compiled by IMD; the $\mathrm{R}^{2}$ from Morck et al. (2000) is a measure of stock return synchronicity and is the $\mathrm{R}^{2}$ from the market model. It is a proxy for informational efficiency with a higher $\mathrm{R}^{2}$ being less informationally efficient. Standard errors are shown in parentheses. 
TABLE 6

Random-effects Regressions: Alternative Tests

\begin{tabular}{|c|c|c|c|c|c|}
\hline Independent variables & $\begin{array}{l}\text { Dollar returns } \\
\text { (1) }\end{array}$ & $\begin{array}{l}\text { VOLRATIO } \\
\text { (2) }\end{array}$ & $\begin{array}{c}\text { EXTRATIO } \\
\text { (3) }\end{array}$ & $\begin{array}{l}\text { SKEW } \\
\text { (4) }\end{array}$ & $\begin{array}{l}\text { SKEW } \\
(5)\end{array}$ \\
\hline Intercept & $\begin{array}{c}0.248 \\
(0.060)\end{array}$ & $\begin{array}{c}0.518 \\
(0.037)\end{array}$ & $\begin{array}{c}0.308 \\
(0.030)\end{array}$ & $\begin{array}{c}0.434 \\
(0.082)\end{array}$ & $\begin{array}{c}0.444 \\
(0.084)\end{array}$ \\
\hline $\begin{array}{l}\text { Skewness } \\
\left(S K E W_{i, t}\right)\end{array}$ & $\begin{array}{c}0.086 \\
(0.004)\end{array}$ & $\begin{array}{c}0.162 \\
(0.005)\end{array}$ & $\begin{array}{c}0.120 \\
(0.004)\end{array}$ & $\begin{array}{c}0.095 \\
(0.005)\end{array}$ & $\begin{array}{c}0.095 \\
(0.005)\end{array}$ \\
\hline $\begin{array}{l}\text { Currency return volatility } \\
\left(S I G M A C U R_{t}\right)\end{array}$ & & $\begin{array}{c}0.031 \\
(0.002)\end{array}$ & $\begin{array}{c}0.009 \\
(0.002)\end{array}$ & $\begin{array}{c}0.021 \\
(0.005)\end{array}$ & $\begin{array}{c}0.021 \\
(0.005)\end{array}$ \\
\hline $\begin{array}{l}\text { Trading volume } \\
\left(T U R N O V E R_{i, t}\right)\end{array}$ & $\begin{array}{c}0.001 \\
(0.001)\end{array}$ & $\begin{array}{l}-0.000 \\
(0.000)\end{array}$ & $\begin{array}{c}0.000 \\
(0.000)\end{array}$ & $\begin{array}{l}-0.002 \\
(0.001)\end{array}$ & $\begin{array}{l}-0.002 \\
(0.001)\end{array}$ \\
\hline $\begin{array}{l}\text { Cumulative return } \\
\left(C U M R E T_{i, t}\right)\end{array}$ & $\begin{array}{l}-0.149 \\
(0.008)\end{array}$ & $\begin{array}{l}-0.100 \\
(0.006)\end{array}$ & $\begin{array}{l}-0.073 \\
(0.004)\end{array}$ & $\begin{array}{l}-0.154 \\
(0.011)\end{array}$ & $\begin{array}{l}-0.155 \\
(0.011)\end{array}$ \\
\hline $\begin{array}{l}\text { Firm size } \\
\left(L N S I Z E_{i, t}\right)\end{array}$ & $\begin{array}{l}-0.039 \\
(0.002)\end{array}$ & $\begin{array}{l}-0.022 \\
(0.001)\end{array}$ & $\begin{array}{l}-0.014 \\
(0.001)\end{array}$ & $\begin{array}{l}-0.041 \\
(0.002)\end{array}$ & $\begin{array}{l}-0.040 \\
(0.002)\end{array}$ \\
\hline $\begin{array}{l}\text { Leverage } \\
\left(L E V E R_{i, t}\right)\end{array}$ & $\begin{array}{c}0.049 \\
(0.025)\end{array}$ & $\begin{array}{l}-0.050 \\
(0.015)\end{array}$ & $\begin{array}{c}0.047 \\
(0.012)\end{array}$ & $\begin{array}{c}0.029 \\
(0.032)\end{array}$ & $\begin{array}{c}0.031 \\
(0.032)\end{array}$ \\
\hline $\begin{array}{l}\text { Market-to-book } \\
\left(M T B_{i, t}\right)\end{array}$ & $\begin{array}{l}-0.009 \\
(0.001)\end{array}$ & $\begin{array}{l}-0.007 \\
(0.001)\end{array}$ & $\begin{array}{c}0.001 \\
(0.000)\end{array}$ & $\begin{array}{l}-0.012 \\
(0.001)\end{array}$ & $\begin{array}{l}-0.012 \\
(0.001)\end{array}$ \\
\hline $\begin{array}{l}\text { GDP per capita } \\
\left(L N G D P_{i, t}\right)\end{array}$ & $\begin{array}{c}0.000 \\
(0.005)\end{array}$ & $\begin{array}{l}-0.025 \\
(0.003)\end{array}$ & $\begin{array}{l}-0.003 \\
(0.003)\end{array}$ & $\begin{array}{l}-0.021 \\
(0.007)\end{array}$ & $\begin{array}{l}-0.024 \\
(0.008)\end{array}$ \\
\hline $\begin{array}{l}\text { Corporate governance index } \\
\text { (CG) }\end{array}$ & $\begin{array}{c}0.109 \\
(0.006)\end{array}$ & $\begin{array}{l}-0.002 \\
(0.003)\end{array}$ & $\begin{array}{c}0.040 \\
(0.003)\end{array}$ & $\begin{array}{c}0.116 \\
(0.007)\end{array}$ & $\begin{array}{c}0.116 \\
(0.007)\end{array}$ \\
\hline $\begin{array}{l}\text { Concentrated ownership } \\
\left(O W N_{t}\right)\end{array}$ & & & & $\begin{array}{c}0.080 \\
(0.032)\end{array}$ & $\begin{array}{c}0.079 \\
(0.032)\end{array}$ \\
\hline $\begin{array}{l}\text { Short-sales constraints } \\
\text { (Short-sales dummy) }\end{array}$ & & & & & $\begin{array}{c}0.018 \\
(0.023)\end{array}$ \\
\hline Year dummy variables & Yes & Yes & Yes & Yes & Yes \\
\hline Industry dummy variables & Yes & Yes & Yes & Yes & Yes \\
\hline$R^{2}$ & 0.040 & 0.075 & 0.048 & 0.043 & 0.043 \\
\hline No. of observations & 67,567 & 67,566 & 65,972 & 45,202 & 45,125 \\
\hline
\end{tabular}

NOTE:- This table presents the results of random-effects regressions to explain return asymmetries across firms and across countries using alternative measures of return asymmetries and regression specifications. The corporate governance index $(C G)$ is the earnings management index (with a higher score indicating more earnings management) and is the aggregate earnings management score reported by Leuz et al. (2003). All other variables are defined in Table 3. The first regression uses dollar-currency returns. The second and third regressions use VOLRATIO and EXTRATIO as the dependent variables, respectively. The fourth regression uses SKEW as the dependent variable and adds concentrated ownership as a control variable. Concentrated ownership in each country is obtained from Worldscope. The fifth regression uses SKEW as the dependent variable and adds a short-sales dummy that takes the value of 1 if a country allows and practices short selling. Standard errors are shown in parentheses. 
TABLE 7

Frequencies of Extremely Negative Daily Returns

\begin{tabular}{|c|c|c|c|c|}
\hline & Return $<-3 \%$ & Return $<-5 \%$ & Return<-7\% & Return $<-10 \%$ \\
\hline \multicolumn{5}{|l|}{ Panel A: Earnings management } \\
\hline Good $(<18.3)$ & $12.50 \%$ & $5.59 \%$ & $2.72 \%$ & $1.05 \%$ \\
\hline Poor $(>=18.3)$ & $12.84 \%$ & $6.38 \%$ & $3.49 \%$ & $1.63 \%$ \\
\hline Difference (Good - Poor) & $-0.34 \%$ & $-0.79 \%$ & $-0.77 \%$ & $-0.58 \%$ \\
\hline p-value (from t-test) & $(0.01)$ & $(0.00)$ & $(0.00)$ & $(0.00)$ \\
\hline \multicolumn{5}{|l|}{ Panel B: Anti-director rights } \\
\hline Good $(>=3)$ & $12.47 \%$ & $5.93 \%$ & $3.07 \%$ & $1.36 \%$ \\
\hline Poor $(<3)$ & $13.80 \%$ & $6.65 \%$ & $3.59 \%$ & $1.52 \%$ \\
\hline Difference (Good - Poor) & $-1.33 \%$ & $-0.72 \%$ & $-0.52 \%$ & $-0.16 \%$ \\
\hline p-value (from t-test) & $(0.00)$ & $(0.00)$ & $(0.00)$ & $(0.86)$ \\
\hline
\end{tabular}

NOTE:- This table reports the frequencies of extremely negative daily returns for countries with good corporate governance versus countries with poor corporate governance. Two measures of corporate governance are used: earnings management and anti-director rights. Countries with an earnings management index above the median $(>=18.3)$ are classified as poor corporate governance countries, while countries with an earnings management index below the median $(<18.3)$ are classified as good corporate governance countries. Similarly, countries with an antidirector index below the median $(<3)$ are classified as poor corporate governance countries, while those above the median ( $>=3$ ) are classified as good corporate governance countries. Panel A reports the result using earnings management as the measure of corporate governance, while Panel B using anti-director rights. We use the t-statistic to test the null hypothesis that the frequencies of extremely negative daily returns between the good and poor corporate governance countries are equal. Numbers in parenthesis are p-values obtained from the t-tests. 
TABLE 8

Random-effects Regressions Using Country Index Returns

\begin{tabular}{|c|c|c|c|c|c|c|}
\hline Independent variables & $\begin{array}{l}\text { Earnings } \\
\text { management } \\
\text { (1) }\end{array}$ & $\begin{array}{l}\text { Anti-director } \\
\text { rights } \\
\text { (2) }\end{array}$ & $\begin{array}{l}\text { Accounting } \\
\text { standards } \\
\text { (3) }\end{array}$ & $\begin{array}{l}\text { Corporate } \\
\text { boards } \\
\text { (4) }\end{array}$ & $\begin{array}{l}\text { Insider } \\
\text { trading } \\
\text { (5) }\end{array}$ & $\begin{array}{l}\mathrm{R}^{2} \text { from } \\
\text { Morck et al. } \\
\text { (6) }\end{array}$ \\
\hline Intercept & $\begin{array}{c}0.557 \\
(0.442)\end{array}$ & $\begin{array}{l}2.096 \\
(0.429)\end{array}$ & $\begin{array}{c}4.823 \\
(1.195)\end{array}$ & $\begin{array}{c}1.509 \\
(0.619)\end{array}$ & $\begin{array}{l}1.353 \\
(0.435)\end{array}$ & $\begin{array}{c}1.411 \\
(0.371)\end{array}$ \\
\hline $\begin{array}{l}\text { Skewness } \\
\left(S K E W_{i, t}\right)\end{array}$ & $\begin{array}{c}0.157 \\
(0.061)\end{array}$ & $\begin{array}{c}0.145 \\
(0.045)\end{array}$ & $\begin{array}{c}0.148 \\
(0.048)\end{array}$ & $\begin{array}{c}0.158 \\
(0.047)\end{array}$ & $\begin{array}{c}0.159 \\
(0.047)\end{array}$ & $\begin{array}{c}0.133 \\
(0.046)\end{array}$ \\
\hline $\begin{array}{l}\text { Currency return volatility } \\
\left(\text { SIGMACUR }_{t}\right)\end{array}$ & $\begin{array}{l}-0.007 \\
(0.021)\end{array}$ & $\begin{array}{l}-0.022 \\
(0.018)\end{array}$ & $\begin{array}{l}-0.050 \\
(0.035)\end{array}$ & $\begin{array}{l}-0.013 \\
(0.019)\end{array}$ & $\begin{array}{l}-0.013 \\
(0.019)\end{array}$ & $\begin{array}{l}-0.008 \\
(0.020)\end{array}$ \\
\hline $\begin{array}{l}\text { Trading volume } \\
\left(\text { TURNOVER } R_{i, t} \text { ) }\right.\end{array}$ & $\begin{array}{l}-0.015 \\
(0.010)\end{array}$ & $\begin{array}{l}-0.015 \\
(0.008)\end{array}$ & $\begin{array}{l}-0.018 \\
(0.010)\end{array}$ & $\begin{array}{l}-0.016 \\
(0.011)\end{array}$ & $\begin{array}{l}-0.016 \\
(0.010)\end{array}$ & $\begin{array}{l}-0.014 \\
(0.008)\end{array}$ \\
\hline $\begin{array}{l}\text { Cumulative return } \\
\left(C U M R E T_{i, t}\right)\end{array}$ & $\begin{array}{l}-0.579 \\
(0.168)\end{array}$ & $\begin{array}{l}-0.457 \\
(0.144)\end{array}$ & $\begin{array}{l}-0.509 \\
(0.158)\end{array}$ & $\begin{array}{l}-0.485 \\
(0.153)\end{array}$ & $\begin{array}{l}-0.482 \\
(0.153)\end{array}$ & $\begin{array}{l}-0.401 \\
(0.152)\end{array}$ \\
\hline $\begin{array}{l}\text { GDP per capita } \\
\left(L N G D P_{i, t}\right)\end{array}$ & $\begin{array}{l}-0.107 \\
(0.038)\end{array}$ & $\begin{array}{l}-0.171 \\
(0.037)\end{array}$ & $\begin{array}{l}-0.109 \\
(0.046)\end{array}$ & $\begin{array}{l}-0.124 \\
(0.047)\end{array}$ & $\begin{array}{l}-0.109 \\
(0.055)\end{array}$ & $\begin{array}{l}-0.111 \\
(0.041)\end{array}$ \\
\hline $\begin{array}{l}\text { Corporate governance } \\
\text { index } \\
(C G)\end{array}$ & $\begin{array}{c}0.158 \\
(0.074)\end{array}$ & $\begin{array}{l}-0.341 \\
(0.116)\end{array}$ & $\begin{array}{l}-0.913 \\
(0.293)\end{array}$ & $\begin{array}{l}-0.188 \\
(0.358)\end{array}$ & $\begin{array}{l}-0.183 \\
(0.263)\end{array}$ & $\begin{array}{c}0.181 \\
(0.081)\end{array}$ \\
\hline Year dummy variables & Yes & Yes & Yes & Yes & Yes & Yes \\
\hline$R^{2}$ & 0.318 & 0.323 & 0.310 & 0.293 & 0.294 & 0.320 \\
\hline No. of observations & 269 & 330 & 302 & 312 & 312 & 303 \\
\hline
\end{tabular}

NOTE:-This table presents the results of random-effects regressions to explain return asymmetries across countries. The dependent variable is $S K E W_{t+1}$ (the coefficient of skewness in year $t+1$ ) that is computed using daily market index returns from each sample country. SIGMACUR $R_{t}$ is the currency volatility measured as the standard deviation of daily currency returns in year $t$. TURNOVER $R_{t}$ is the average daily market turnover in year $t$. CUMRET is the cumulative market return over year t. $L N G D P_{t}$ is the logarithm of GDP per capita (in U.S. dollars) in year $t$. The corporate governance index $(C G)$ includes earnings management, anti-director rights, accounting standards, corporate boards, insider trading, and the $\mathrm{R}^{2}$ measure. Earnings management (with a higher score indicating more earnings management) is the aggregate earnings management score reported by Leuz et al. (2003); anti-director rights (with a higher score indicating better shareholder rights) and accounting standards (with a higher score indicating higher accounting quality) are taken from La Porta et al. (1998); corporate boards (with a higher score indicating more effective boards) and insider trading (with a higher score indicating less inside trading) are index scores compiled by IMD; the $\mathrm{R}^{2}$ from Morck et al. (2000) is a measure of stock return synchronicity and is the $\mathrm{R}^{2}$ from the market model. It is a proxy for informational efficiency with a higher $\mathrm{R}^{2}$ being less informationally efficient. Standard errors are shown in parentheses. 